Utah State University

DigitalCommons@USU

Articles

Publications

7-7-2015

\title{
Structural and Functional Connectivity as a Driver of Hillslope Erosion Following Disturbance
}

Christopher Jason Williams

USDA, Agricultural Research Service

Frederick B. Pierson

USDA, Agricultural Research Service

Peter R. Robichaud

USDA Forest Service

Osama Z. Al-Hamdan

USDA, Agricultural Research Service

Jan Boll

University of Idaho

Eva K. Strand

University of Idaho

Follow this and additional works at: https://digitalcommons.usu.edu/sagestep_articles

Part of the Plant Sciences Commons

\section{Recommended Citation}

Williams, C.J., F.B. Pierson, P.R. Robichaud, O.Z. Al-Hamdan, J. Boll, and E.K. Strand. 2016. Structural and functional connectivity as a driver of hillslope erosion following disturbance. International Journal of Wildland Fire 25:306-321.

This Article is brought to you for free and open access by the Publications at DigitalCommons@USU. It has been accepted for inclusion in Articles by an authorized administrator of DigitalCommons@USU. For more information, please contact digitalcommons@usu.edu.

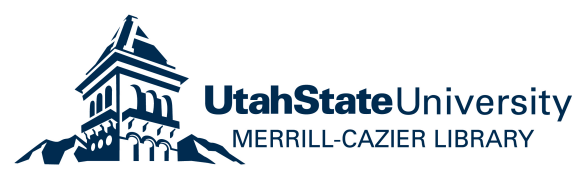




\title{
Structural and functional connectivity as a driver of hillslope erosion following disturbance
}

\author{
C. Jason Williams ${ }^{\mathrm{A}, \mathrm{B}, \mathrm{F}}$, Frederick B. Pierson ${ }^{\mathrm{A}}$, Peter R. Robichaud ${ }^{\mathrm{C}}$, \\ Osama Z. Al-Hamdan ${ }^{\mathrm{A}, \mathrm{D}}$, Jan Boll ${ }^{\mathrm{B}, \mathrm{D}}$ and Eva K. Strand ${ }^{\mathrm{E}}$ \\ ${ }^{A}$ Northwest Watershed Research Center, Agricultural Research Service, USDA, \\ 800 Park Boulevard, Plaza 4, Suite 105, Boise, ID 83712, USA. \\ ${ }^{B}$ Environmental Science and Water Resources, University of Idaho, 875 Perimeter Drive, \\ MS 1142, Moscow, ID 83844-1142, USA.

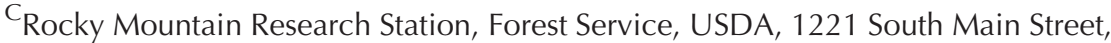 \\ Moscow, ID 83843, USA. \\ D Department of Biological and Agricultural Engineering, University of Idaho, \\ 875 Perimeter Drive, MS 0904, Moscow, ID 83844-0904, USA. \\ ${ }^{E}$ Department of Forest, Rangeland, and Fire Sciences, University of Idaho, \\ 875 Perimeter Drive, MS 1133, Moscow, ID 83844-1133, USA. \\ ${ }^{\mathrm{F}}$ Corresponding author: Email: jason.williams@ars.usda.gov
}

\begin{abstract}
Hydrologic response to rainfall on fragmented or burnt hillslopes is strongly influenced by the ensuing connectivity of runoff and erosion processes. Yet cross-scale process connectivity is seldom evaluated in field studies owing to scale limitations in experimental design. This study quantified surface susceptibility and hydrologic response across point to hillslope scales at two degraded unburnt and burnt woodland sites using rainfall simulation and hydrologic modelling. High runoff (31-47 mm) and erosion (154-1893 $\left.\mathrm{g} \mathrm{m}^{-2}\right)$ measured at the patch scale $\left(13 \mathrm{~m}^{2}\right)$ were associated with accumulation of fine-scale $\left(0.5-\mathrm{m}^{2}\right)$ splash-sheet runoff and sediment and concentrated flow formation through contiguous bare zones (64-85\% bare ground). Burning increased the continuity of runoff and sediment availability and yield. Cumulative runoff was consistent across plot scales whereas erosion increased with increasing plot area due to enhanced sediment detachment and transport. Modelled hillslope-scale runoff and erosion reflected measured patch-scale trends and the connectivity of processes and sediment availability. The cross-scale experiments and model predictions indicate the magnitude of hillslope response is governed by rainfall input and connectivity of surface susceptibility, sediment availability, and runoff and erosion processes. The results demonstrate the importance in considering cross-scale structural and functional connectivity when forecasting hydrologic and erosion responses to disturbances.
\end{abstract}

Additional keywords: ecohydrology, fire effects, infiltration, risk assessment, runoff, soil erosion, vegetation transition, wildfire, woodland encroachment.

Received 26 June 2014, accepted 9 April 2015, published online 7 July 2015

\section{Introduction}

The patchy attributes of rangelands provide unique landscapes for investigating the dynamic interaction of structural and functional connectivity that propagates hillslope runoff and erosion response (Ludwig et al. 1997; Wainwright et al. 2000; Bracken and Croke 2007; Turnbull et al. 2008; Reaney et al. 2014; Williams et al. 2014a, 2014b). Here, we define structural connectivity as the connectivity of surface conditions that are susceptible to runoff generation and sediment detachment and transport (Williams et al. 2014a), as indicated primarily by the percentage of bare ground (Johansen et al. 2001; BenavidesSolorio and MacDonald 2005; Wagenbrenner et al. 2006; Pierson et al. 2008a, 2009, 2010, 2013; Williams et al. 2014b). By functional connectivity, we are referring to the connectivity of runoff and erosion processes (mainly rainsplash, sheetflow and concentrated flow) along a hillslope (Turnbull et al. 2008; Reaney et al. 2014; Williams et al. 2014a, 2014b). Hillslope surface runoff and erosion from well-vegetated rangelands are low owing to spatial heterogeneity in infiltration, runoff sources, and sediment detachment and deposition (Pierson et al. 1994; Puigdefábregas et al. 1999; Wilcox et al. 2003; Ludwig et al. 2005; Puigdefábregas 2005; Pierson et al. 2009). Isolated bare patches between plant canopies (interspaces) are sources for runoff generation and soil detachment by rainsplash and sheetflow (splash-sheet). Patches of vegetation and ground cover intercept and store rainfall and overland flow, facilitate infiltration and sediment retention, and protect the ground surface from raindrop impact and detachment by flow. Plant community 
degradation associated with disturbances often results in increased surface runoff and soil loss due to fragmentation of the vegetation and ground cover patch-structure (Abrahams et al. 1995; Wilcox et al. 1996; Wainwright et al. 2000; Pierson et al. 2010; Turnbull et al. 2010a, 2010b; Williams et al. 2014b). Following degradation, patches of bare ground become connected (structural connectivity), increasing the continuity of potential runoff and erosion sources (Davenport et al. 1998; Turnbull et al. 2008; Bracken et al. 2013; Williams et al. 2014a, $2014 b)$. Splash-sheet processes occurring at fine scales $\left(<1 \mathrm{~m}^{2}\right)$ become sources for runoff and erosion delivery to coarse scales (tens to hundreds of square metres) where other runoff and erosion processes become active (functional or process connectivity) (Wainwright et al. 2000; Bracken and Croke 2007; Turnbull et al. 2008; Pierson et al. 2011; Williams et al. 2014a, $2014 b$ ). Partitioning of plot-based experiments by patch type over different spatial scales pre- and post degradation provides a basis for evaluating effects of dynamic structural and functional connectivity on cross-scale sediment delivery (Bracken and Croke 2007; Wainwright et al. 2000; Wilcox et al. 2003; Pierson et al. 2009, 2010, 2013).

Fire increases the risk for hillslope and watershed-scale runoff and erosion through alteration of vegetation and ground-cover patch structure (Puigdefábregas 2005; Shakesby and Doerr 2006; Pierson et al. 2011; Williams et al. 2014a). Rain falling on bare soil is rapidly converted to runoff, particularly where water-repellent soil conditions exist (Shakesby et al. 2000; Pierson et al. 2008a, 2008b; Williams et al. 2014b). Burnt bare soils also provide a source of readily detached soil (Cannon et al. 2001a; Wagenbrenner et al. 2010; Al-Hamdan et al. 2012a; Nyman et al. 2013). Ample runoff generation and splash-detached sediment at fine scales are transferred to coarse scales through sheetflow and high-velocity concentrated flow over contiguous burnt and bare areas (Benavides-Solorio and MacDonald 2005; Spigel and Robichaud 2007; Pierson et al. 2009, 2011, 2013; Williams et al. 2014a, 2014b). Over hillslope and watershed scales, connectivity of burnt-area runoff and sediment sources during high-intensity storms commonly results in flooding, mudslides, and debris flows and damage to resources, property and life (Cannon et al. 1998, 2001b; Moody and Martin 2001a; Pierson et al. 2002; Neary et al. 2012). Understanding of the mechanisms that facilitate hydrologic and erosion process (functional) connectivity is paramount in mitigating hillslope and watershed responses to high-intensity rainfall events (Moody et al. 2013; Robichaud et al. 2013a, 2013b; Wagenbrenner and Robichaud 2013; Williams et al. 2014a).

Recent advancements in hydrologic modelling have increased the ability to predict the effects of structural and functional or process connectivity on sediment delivery from disturbed rangelands (Robichaud et al. 2007; Nearing et al. 2011; Al-Hamdan et al. 2015). For example, the Rangeland Hydrology and Erosion Model (RHEM; Nearing et al. 2011) was developed from diverse rangeland datasets for predicting runoff and erosion responses on rangelands (Wei et al. 2009; Al-Hamdan et al. 2012a, 2012b, 2013). RHEM is a modified version of the Water Erosion Prediction Project (WEPP) model (Flanagan and Nearing 1995) and was recently enhanced for runoff and erosion prediction from disturbed hillslopes
(Al-Hamdan et al. 2015). The enhanced version, RHEM 2.1, utilises the KINEROS2 model (Smith et al. 1995) for simulation of hydrologic processes (Al-Hamdan et al. 2015). Infiltration and soil erodibility in RHEM are parameterised as a function of vegetation, ground cover and soil texture (Nearing et al. 2011; Al-Hamdan et al. 2012a). Sediment delivery rate in RHEM is the total detachment rate of splash-sheet and concentrated flow using a dynamic partial differential sediment continuity equation (Al-Hamdan et al. 2015). Splash-sheet detachment in RHEM is a function of splash-sheet soil erodibility and rainfall intensity (Wei et al. 2009). Soil detachment by concentrated flow uses the stream-power-based erodibility and modelcalculated hydraulic flow parameters (Al-Hamdan et al. $2012 a, 2012 b, 2013,2015)$. Parameterisation of RHEM occurs through the model interface and can be amended by the user through an input file. RHEM parameter estimation equations and the model documentation are available at http://apps.tucson. ars.ag.gov/rhem/docs (accessed 20 June 2014).

The need to understand the effects of structural and functional connectivity on cross-scale runoff and erosion responses is well established (Kutiel et al. 1995; de Vente and Poesen 2005; Bracken and Croke 2007; Turnbull et al. 2008; Cantón et al. 2011; Bracken et al. 2013; Moody et al. 2013). However, few studies experimentally partition and quantify runoff and erosion processes at multiple spatial scales (Wagenbrenner and Robichaud 2013), limiting inferences on connectivity. The present study quantifies runoff and erosion across point to hillslope scales on multiple degraded and burnt rangeland sites. Our goal is to provide tangible evidence of the evolution of cross-scale functional or process connectivity associated with increased structural connectivity and the impact of cross-scale structural and functional connectivity on hillslope-scale sediment yield. A suite of rainfall simulation and hydrologic modelling techniques were used to measure and predict runoff and erosion at various spatial scales for two degraded and burnt woodland-encroached shrublands in the Great Basin, USA. The primary objectives were: (1) quantify vegetation and ground cover, and runoff and erosion by splash-sheet processes in interspaces and in areas underneath tree and shrub canopies (coppice mounds); (2) quantify vegetation and ground cover, and runoff and erosion by combined splash-sheet and concentrated-flow processes within the intercanopy and in areas underneath tree canopies; (3) compare measured runoff and erosion rates across small-plot $\left(0.5-\mathrm{m}^{2}\right)$ to large-plot $\left(13-\mathrm{m}^{2}\right)$ scales; and (4) evaluate the influence of plot-scale cover and hydrologic and erosion processes on contributions of runoff and erosion at the hillslope scale.

\section{Methods}

Study sites

Data were collected in a single-leaf pinyon-Utah juniper (Pinus monophylla Torr. and Frém.- Juniperus osteosperma [Torr.] Little) woodland (Marking Corral site) and a Utah juniper woodland (Onaqui site) 1-3 months before (2006, Year 0) and $\sim 12$ months following prescribed fire (2007, Year 1). The Marking Corral site (lat. $39^{\circ} 27^{\prime} 17^{\prime \prime} \mathrm{N}$, long. $115^{\circ} 06^{\prime} 51^{\prime \prime} \mathrm{W}$ ) is located in the Egan Range, $\sim 27 \mathrm{~km}$ north-west of Ely, Nevada, USA. The Onaqui site (lat. $40^{\circ} 12^{\prime} 42^{\prime \prime} \mathrm{N}$, long. $112^{\circ} 28^{\prime} 24^{\prime \prime} \mathrm{W}$ ) is 
Table 1. Topography, climate, soil, tree cover and common understorey vegetation at the Marking Corral and Onaqui sites immediately before fire Data from Pierson et al. (2010), except where indicated by footnote

\begin{tabular}{|c|c|c|}
\hline & Marking Corral, Nevada, USA & Onaqui, Utah, USA \\
\hline Woodland community & Single-leaf pinyon ${ }^{\mathrm{A}}-$ Utah juniper $^{\mathrm{B}}$ & Utah juniper ${ }^{\mathrm{B}}$ \\
\hline Elevation (m) & 2250 & 1720 \\
\hline Mean annual precipitation (mm) & $382^{\mathrm{C}}$ & $468^{\mathrm{C}}$ \\
\hline Mean annual air temperature $\left({ }^{\circ} \mathrm{C}\right)$ & $7.2^{\mathrm{D}}$ & $7.5^{\mathrm{E}}$ \\
\hline Slope (\%) & $10-15$ & $10-15$ \\
\hline Parent rock & Andesite and rhyolite ${ }^{\mathrm{F}}$ & Sandstone and limestone ${ }^{\mathrm{G}}$ \\
\hline Soil association & Sequra-Upatad-Cropper ${ }^{\mathrm{F}}$ & Borvant $^{G}$ \\
\hline Depth to bedrock (m) & $0.4-0.5^{\mathrm{F}}$ & $1.0-1.5^{\mathrm{G}}$ \\
\hline Soil surface texture & Sandy loam, $66 \%$ sand, $30 \%$ silt, $4 \%$ clay & Sandy loam, $56 \%$ sand, $37 \%$ silt, $7 \%$ clay \\
\hline Tree canopy cover $(\%)^{\mathrm{H}}$ & $21^{\mathrm{A}}, 6^{\mathrm{B}}$ & 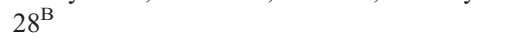 \\
\hline Trees per hectare ${ }^{\mathrm{H}}$ & $465^{\mathrm{A}}, 114^{\mathrm{B}}$ & $532^{\mathrm{B}}$ \\
\hline Mean tree height $(\mathrm{m})^{\mathrm{H}}$ & $2.3^{\mathrm{A}}, 1.9^{\mathrm{B}}$ & $2.3^{\mathrm{B}}$ \\
\hline Common understorey plants & \multicolumn{2}{|c|}{$\begin{array}{l}\text { Artemisia tridentata Nutt. ssp. wyomingensis Beetle and Young; Artemisia nova A. Nelson; Purshia spp.; } \\
\text { Poa secunda J. Presl; Pseudoroegneria spicata (Pursh) A. Löve; and various forbs }\end{array}$} \\
\hline
\end{tabular}

A Pinus monophylla Torr. and Frém.

${ }^{\mathrm{B}}$ Juniperus osteosperma [Torr.] Little.

${ }^{C}$ Estimated for years 1980-2011 (Thornton et al. 2012); Pierson et al. (2010) estimate (351 mm Marking Corral, $345 \mathrm{~mm}$ Onaqui) was based on data from Prism Group (2009) for years 1971-2000.

${ }^{D}$ Western Regional Climate Center (WRCC), Station 264199-2, Kimberly, Nevada (WRCC 2009).

${ }^{\mathrm{E}}$ WRCC, Station 424362-3, Johnson Pass, Utah (WRCC 2009).

${ }^{\mathrm{F}}$ Natural Resources Conservation Service (NRCS) 2007.

${ }^{\mathrm{G}} \mathrm{NRCS} 2006$

${ }^{\mathrm{H}}$ Data from Pierson et al. (2010), but restricted to the area subsequently burned. Data for trees $>1 \mathrm{~m}$ height only.

located in the Onaqui Mountains, $76 \mathrm{~km}$ south-west of Salt Lake City, Utah, USA. Site-level topography, climate, soils and common vegetation are described in Table 1. Prescribed fires were implemented on portions of both sites in autumn 2007. Burn severity was not quantified, but presence of residual and scorched tree needles, shrub skeletons, blackened litter and downed woody debris immediately post-fire at both sites were indicative of low to moderate burn severity for woodlands (Parsons et al. 2010). Individual tree canopy scorch averaged $50-75 \%$ at Marking Corral and $75-99 \%$ at Onaqui (Pierson et al. 2014).

\section{Experimental design}

Small-plot $(0.7 \times 0.7-\mathrm{m})$ rainfall simulation experiments were used to quantify fine-scale effects of vegetation and surface conditions on runoff and erosion from splash-sheet processes. Small plots at each site were installed before burning (Year 0) using methodology described in Pierson et al. (2010). Small plots were placed on individual tree and shrub coppices and in the interspaces between tree and shrub coppices in order to partition respective microsite runoff and erosion contributions to the large-plot scale. Vegetation and ground cover and rainfall simulation data were collected on all small plots in Year 0 (Pierson et al. 2010) and as repeated measures in burnt and unburnt areas in Year 1. Only the Year 1 small-plot data are used in the current study. The number of small plots sampled in Year 1 for each site $\times$ microsite $\times$ treatment combination is shown in Table 2. Average slope gradient for small plots was $12 \%$ at Marking Corral and $18 \%$ at Onaqui.

Large-rainfall simulation plots $(2 \mathrm{~m}$ wide $\times 6.5 \mathrm{~m}$ long $)$ were used to quantify effects of vegetation and surface conditions on runoff and erosion from combined splash-sheet and concentrated-flow processes at the patch scale. Large plots were randomly selected and installed in pairs using methodology described in Pierson et al. (2010). Each large plot was placed on either a tree zone (area underneath and immediately adjacent to tree canopies) or shrub-interspace zone (intercanopy area outside of tree canopy influence). Six large plots per zone type were installed and sampled at each site in Year 0 before burning, but within the area subsequently burned. One year post-fire, six new large plots per zone type were installed and sampled within burnt areas at each site. Average slope gradient for large plots was 9\% at Marking Corral and 18\% at Onaqui across both study years. Trees were trimmed or removed from small and large rainfallsimulation plots immediately preceding experiments to minimise canopy interference with rainfall and plot sampling. Shrubs were retained on plots, but were trimmed along plot boundaries to prevent stemflow from exiting or entering the plot.

Hillslope-scale runoff and erosion were modelled with the RHEM model. Model runs were constructed for burnt and unburnt conditions based on site biophysical attributes (Table 1) and measured vegetation and ground cover from $30 \times 33$-m sitecharacterisation plots. Three site-characterisation plots were randomly located, marked for subsequent sampling, and sampled for vegetation and ground cover within the burn treatment area at each site in Year 0 before burning. The same three sitecharacterisation plots at each site were resampled as repeated measures 1 year post-fire.

\section{Small-plot scale}

Canopy (foliar) cover, ground cover (basal plant, cryptogams, litter, rock (fragment $>5 \mathrm{~mm}$ ), woody dead, and bare soil), and 


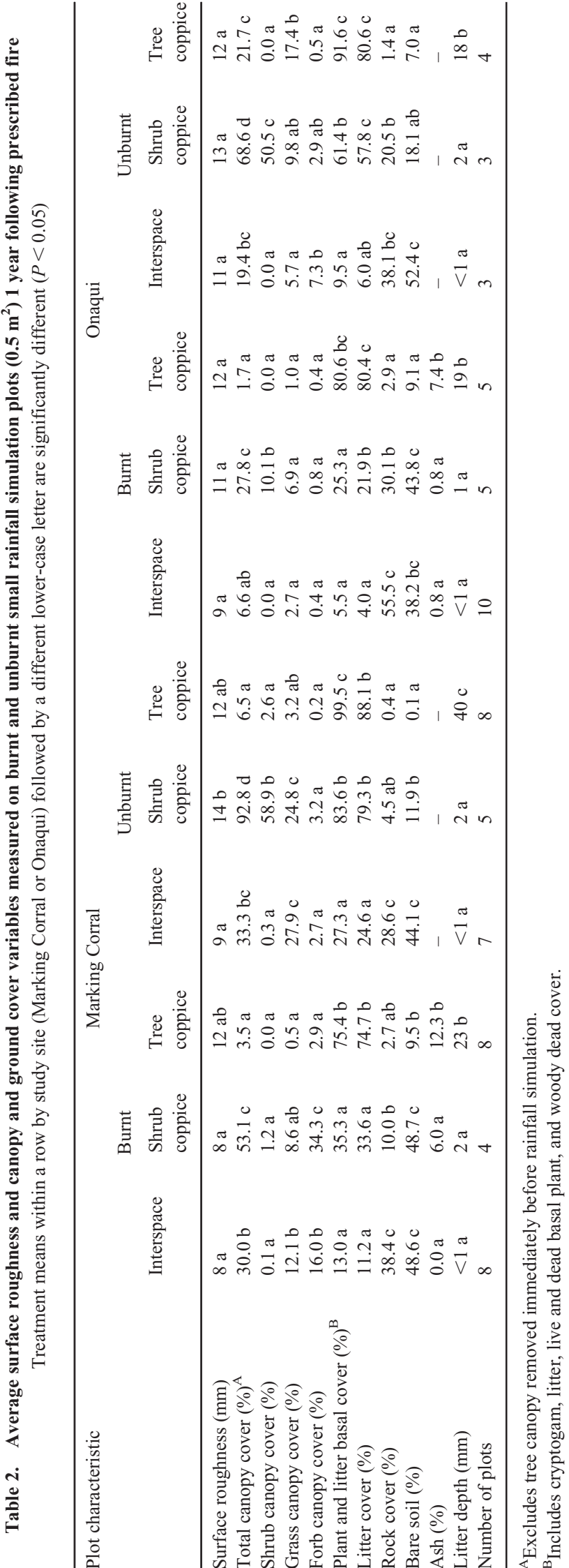

ground surface roughness were measured using point frame methodologies (Pierson et al. 2010). Canopy and ground cover for each plot were recorded at 15 points (spaced $5 \mathrm{~cm}$ apart) along each of seven evenly spaced transects $(10 \mathrm{~cm}$ apart and parallel to hillslope contour) for a total of 105 points per plot. Percentage cover for each cover type on a plot was derived from the frequency of hits divided by the total number of points sampled within the plot. The relative ground surface height at each sample point was measured by steel ruler as the distance between the point frame level line and the ground surface. Ground surface roughness on each plot was estimated as the arithmetic average of the standard deviations of the ground surface heights for each of the seven transects sampled on the respective plot. Litter depth on each plot was measured by steel ruler to the nearest $1 \mathrm{~mm}$ at four evenly spaced points $(\sim 15-\mathrm{cm}$ spacing) along the outside edge of each of the two plot borders oriented perpendicular to the hillslope contour. Plot average litter depth was calculated as the mean of the eight litter depths measured.

Soil water repellency and antecedent soil moisture conditions on each plot were assessed before rainfall simulation each year. Soil water repellency was assessed immediately adjacent (within $\sim 50 \mathrm{~cm}$ ) to each plot using the water drop penetration time (WDPT) method (DeBano 1981). Eight water drops ( $3-\mathrm{cm}$ spacing) were applied to the mineral soil surface (ash and litter removed) and the time required for infiltration of each drop was recorded up to $300 \mathrm{~s}$. Following this procedure, $1 \mathrm{~cm}$ of soil was excavated immediately underneath the previously sampled area and the WDPT method was repeated for an additional eight drops. This process was repeated until a depth of $5 \mathrm{~cm}$ was sampled. The mean WDPT at 0-, 1-, 2-, 3-, 4- and 5-cm soil depths for each plot was recorded as the mean of the eight WDPT samples at the respective depth. Water repellency strength at each sampled depth was classified as 'slight' if mean WDPT ranged from 5 to $60 \mathrm{~s}$ and 'strong' if mean WDPT ranged from 60 to $300 \mathrm{~s}$ (Bisdom et al. 1993). Soils were considered wettable where mean WDPT $<5 \mathrm{~s}$. Surface soil samples were obtained for $0-5-\mathrm{cm}$ depth adjacent to the WDPT sampling and were later analysed in the laboratory for gravimetric soil water content.

An oscillating-arm rainfall simulator fitted with $80-100$ Veejet (Spraying Systems Co., Wheaton, IL) nozzles was used to apply rainfall on each small plot. The simulator design, raindrop characteristics and rainfall calibration methods are described by Pierson et al. (2008a, 2009, 2010). Rainfall was applied to each plot at target rates of $64 \mathrm{~mm} \mathrm{~h}^{-1}$ under dry (dry-run) and $102 \mathrm{~mm} \mathrm{~h}^{-1}$ under wet (wet-run) antecedent soil moisture conditions for $45 \mathrm{~min}$ each. The dry- and wet-run simulations were separated by a 30 -min hiatus. Only the wet-run data are used for the current study. The mean rainfall applied was similar across burnt and unburnt conditions at a site $(P>0.05)$.

Timed samples of plot runoff were collected over 1- to 3-min intervals throughout each 45-min rainfall simulation and were analysed in the laboratory for runoff volume and sediment concentration as described in Pierson et al. (2010). Hydrologic and erosion response variables were derived for each plot based on the timed runoff samples. A mean runoff rate $\left(\mathrm{mm} \mathrm{h}^{-1}\right)$ was calculated for each sample interval as the cumulative runoff divided by the interval time. Cumulative runoff $(\mathrm{mm})$ was 
calculated as the integration of runoff rates over the total time of runoff. The percentage of rainfall converted to runoff on each plot was calculated as a runoff-to-rainfall ratio $\left(\mathrm{mm} \mathrm{mm}^{-1}\right)$, cumulative runoff divided by cumulative rainfall applied and multiplied by $100 \%$. Infiltration and sediment variables were calculated for plots that generated runoff. An average infiltration rate $\left(\mathrm{mm} \mathrm{h}^{-1}\right)$ for each sample interval was calculated as the difference between applied rainfall and measured runoff divided by the sample interval duration. Cumulative sediment yield $\left(\mathrm{g} \mathrm{m}^{-2}\right)$ was the integrated sum of sediment collected during runoff and was extrapolated to a unit area by dividing cumulative sediment by plot area. A sediment-to-runoff ratio $\left(\mathrm{g} \mathrm{m}^{-2} \mathrm{~mm}^{-1}\right.$ ) was obtained by dividing cumulative sediment yield per unit area by cumulative runoff.

\section{Large-plot scale}

Canopy and ground cover on each large plot were recorded at 59 points $(10 \mathrm{~cm}$ apart) along each of five evenly spaced $(40 \mathrm{~cm}$ apart, perpendicular to hillslope contour) transects $6 \mathrm{~m}$ in length for a total 295 points per plot. Percentage cover for each cover type was derived for each plot as the frequency of hits divided by the total number of points sampled. The relative ground-surface height along line-point transects was measured as the distance between the ground surface and a survey transit level line over the respective sample point. Ground surface roughness of each plot was estimated as the average of the standard deviations of the ground surface heights across the five line-point transects sampled within the respective plot.

Paired large-plot rainfall simulations were conducted with a Colorado State University-type rainfall simulator described by Holland (1969) and Pierson et al. (2009, 2010). The simulator consists of seven stationary sprinklers elevated $3.05 \mathrm{~m}$ above the ground surface and evenly spaced along each of the outermost borders of the respective rainfall-plot pair. Target rainfall rates and application sequences were consistent with those for small plots. Total rainfall applied to each large plot was determined from the average of six plastic depth gauges in a uniform grid (Pierson et al. 2010). The mean rainfall applied was similar across burnt and unburnt conditions at a site $(P>0.05)$. Timed samples of plot runoff were collected over 1- to 3-min intervals throughout each 45-min rainfall simulation and were analysed in the laboratory for runoff volume and sediment concentration as described in Pierson et al. (2010). Large-plot hydrologic and erosion response variables were derived using the same methods used for the small-plot simulations.

Differences in runoff and erosion across small- to large-plot scales were evaluated by comparing measured large-rainfallplot runoff and erosion with area-weighted small-rainfall-plot data (Pierson et al. 1994, 2009, 2010; Williams et al. 2014b). The proportions of interspace, shrub coppice and tree coppice area on each large plot were determined from the large-plot canopy and ground-cover measurements. For unburnt shrubinterspace plots, percentage shrub canopy cover was used as an estimate of the shrub coppice proportional area; the remaining plot area was considered interspace. For unburnt tree zone plots, the difference in percentage litter and percentage shrub canopy cover was used to estimate proportional tree coppice area, and percentage shrub cover was used to estimate proportional shrub coppice area. The proportional interspace area in unburnt tree zones was estimated as the remaining percentage plot area after deducting, from $100 \%$, the estimated shrub and tree coppice coverage. The pre-fire representative areas of interspace and shrub and juniper coppice could not be determined for burnt large plots. Therefore, mean microsite area estimates from unburnt shrub-interspace and tree zones were used to estimate small-plot microsite coverage within burnt shrub-interspace and tree zones respectively. Total area and cover for each area-weighted large plot were $13 \mathrm{~m}^{2}$ and $100 \%$ cover. Cumulative runoff and sediment yield for each area-weighted large plot was obtained by multiplying mean cumulative small-plot runoff and erosion values for the respective burnt or unburnt microsites by the estimated representative microsite proportional areas and summing the results for the entire plot.

\section{Hillslope scale}

Hillslope-scale understorey canopy and ground cover were measured on each $30 \times 33-\mathrm{m}$ plot using the line-point intercept method along five 30-m transects installed 5-8 $\mathrm{m}$ apart and perpendicular to hillslope contour (Pierson et al. 2010). Plot canopy and ground cover were recorded at 60 points with $50-\mathrm{cm}$ spacing along each of the five transects for a total of 300 sample points per plot. Percentage cover for each cover type was derived for each plot as the frequency of hits divided by the total number of points sampled.

The RHEM model (version 2.1; Nearing et al. 2011; Al-Hamdan et al. 2015) was used to predict hillslope-scale runoff and erosion for burnt and unburnt conditions at both study sites. RHEM requires the following user input: (1) climate data (via internal CLIGEN climate generator); (2) surface soil texture class (upper $4 \mathrm{~cm}$ of soil profile); (3) hillslope length, gradient and shape (uniform, convex, concave, or s-shaped); and (4) percentage vegetation and ground cover by lifeform or cover class (litter and rock). Baseline RHEM model runs were created for each study site using climate, topographic and soils characteristics consistent with those shown in Table 1. For Marking Corral, the baseline RHEM model was constructed as follows: (1) climate station - Ruby Lake, Nevada (station ID: 267123, $1832 \mathrm{~m}$ elevation, $319 \mathrm{~mm}$ annual precipitation); (2) sandy loam soil texture; and (3) 30-m hillslope length, 10\% slope and uniform slope shape. For Onaqui, the baseline RHEM model was constructed as follows: (1) climate station - Tooele, Utah (station ID: 428771, $1470 \mathrm{~m}$ elevation, $432 \mathrm{~mm}$ annual precipitation); (2) sandy loam soil texture; and (3) 30-m hillslope length, $15 \%$ slope and uniform slope shape. Burnt and unburnt simulations were created by populating canopy and ground cover (as measured on the $30 \times 33-\mathrm{m}$ site-characterisation plots) for the respective conditions within the site-specific baseline models.

The effect of concentrated-flow processes on hillslopescale sediment delivery was assessed through RHEM predictions utilising splash-sheet-dominated and concentrated-flow-dominated erodibility parameterisation schemes. The splash-sheet-dominated erodibility scheme is the default parameterisation in RHEM and applies a very low erodibility $\left(0.003 \times 10^{-3} \mathrm{~s}^{2} \mathrm{~m}^{-2}\right)$ to detachment by concentrated flow, typical for undisturbed vegetation and surface conditions. 
Therefore, sediment yield predicted by RHEM with the default concentrated-flow erodibility is primarily accumulated as splash-sheet detached sediment, transported by combined splash-sheet and concentrated overland flow mechanisms (Al-Hamdan et al. 2015). The default concentrated-flow detachment capacity $\left(D_{c}\right)$ in RHEM is calculated with the following equation (Al-Hamdan et al. 2012a):

$$
D_{c}=K_{\omega \_d e f}(\omega)
$$

where $K_{\omega \_d e f}$ is the stream-power-based default concentratedflow erodibility $\left(\mathrm{s}^{2} \mathrm{~m}^{-2}\right)$, and $\omega$ is model-derived stream power $\left(\mathrm{kg} \mathrm{s}^{-3}\right)$. We applied RHEM with Eqn 1 in this study to predict hillslope-scale erosion at both sites under splash-sheet-dominated processes for burnt and unburnt conditions. For the concentrated-flow-dominated scheme, we applied concentrated flow parameterisation equations developed by Al-Hamdan et al. $(2012 a, 2012 b, 2013,2015)$ specifically for application of RHEM to woodland-encroached and burnt rangelands. The RHEM concentrated-flow-dominated simulations for unburnt conditions utilised the same form of the detachment capacity in Eqn 1. However, the low default concentrated-flow erodibility, $K_{\omega \_d e f}$, was replaced with a calculated concentrated-flow erodibility, $K_{\omega}\left(\mathrm{s}^{2} \mathrm{~m}^{-2}\right)$, suggested by Al-Hamdan et al. (2012a, 2015):

$\log \left(K_{\omega}\right)=-4.14-1.28$ res -0.98 rock -15.16 clay +7.09 silt

where the variables res, rock, clay, and silt are respectively the decimal percentages of residue (litter), surface rock cover, and surface soil clay and silt contents. For application of RHEM to burnt conditions, Al-Hamdan et al. (2015) suggested use of a dynamic stream-power-based concentrated-flow erodibility approach that decays from a maximum value $\left(K_{\omega(\max )}\right)$ during the course of a runoff event. Concentrated-flow detachment capacity for the dynamic approach in RHEM is calculated as:

$$
D_{c}=\left[(P)\left(K_{\omega(\max )} e^{\beta q_{c}}\right)+(1-P)\left(K_{\omega}\right)\right](\omega)
$$

where $P$ is the decimal probability of overland flow to concentrate, $K_{\omega(\max )}$ is a user calculated maximum concentrated flow erodibility $\left(\mathrm{s}^{2} \mathrm{~m}^{-2}\right)$ at the time of runoff initiation, $\beta$ is an erodibility decay factor $\left(-5.53 \mathrm{~m}^{-2}\right), q_{c}$ is cumulative unit flow discharge $\left(\mathrm{m}^{2}\right), K_{\omega}$ is the baseline concentrated flow erodibility $\left(\mathrm{s}^{2} \mathrm{~m}^{-2}\right)$ from Eqn 2, and $\omega$ is stream power $\left(\mathrm{kg} \mathrm{s}^{-3}\right)$. The variables $P, q_{c}$ and $\omega$ are derived internally and applied by RHEM as described by Al-Hamdan et al. (2012a, 2013, 2015). For the concentrated-flow-dominated scheme on burnt conditions, $K_{\omega(\max )}$ was calculated with the following equation from Al-Hamdan et al. (2015).

$$
\begin{aligned}
\log \left(K_{\omega(\max )}\right)= & -3.64-1.97(\text { res }+ \text { bascry })-1.85 \text { rock } \\
& -4.99 \text { clay }+6.06 \text { silt }
\end{aligned}
$$

where the variable bascry is the decimal percentage of the sum of basal and cryptogam covers and all other variables are as described for Eqn 2. The ground-cover data required to calculate
$K_{\omega}$ and $K_{\omega(\max )}$ for application to burnt and unburnt conditions were obtained from the $30 \times 33-\mathrm{m}$ site-characterisation plots. Soil particle size data for the modelled conditions were obtained from Pierson et al. (2010; Table 1). The calculated erodibility parameters for Marking Corral RHEM simulations were as follows: (1) for burnt conditions, $K_{\omega(\max )}=1.129 \times 10^{-3} \mathrm{~s}^{2} \mathrm{~m}^{-2}$ and $K_{\omega}=0.656 \times 10^{-3} \mathrm{~s}^{2} \mathrm{~m}^{-2}$; and (2) for unburnt conditions, $K_{\omega}=0.335 \times 10^{-3} \mathrm{~s}^{2} \mathrm{~m}^{-2}$. For Onaqui RHEM simulations, the calculated erodibility parameters were as follows: (1) for burnt conditions, $K_{\omega(\max )}=1.067 \times 10^{-3} \mathrm{~s}^{2} \mathrm{~m}^{-2}$ and $K_{\omega}=0.540 \times$ $10^{-3} \mathrm{~s}^{2} \mathrm{~m}^{-2}$; and (2) for unburnt conditions, $K_{\omega}=0.498 \times$ $10^{-3} \mathrm{~s}^{2} \mathrm{~m}^{-2}$. Al-Hamdan et al. (2015) found that the applied erodibility parameterisation schemes yielded estimated erosion rates within field measurement error for measured erosion rates (rainfall simulations, $13-\mathrm{m}^{2}$ plots, $102-\mathrm{mm} \mathrm{h}^{-1}$ intensity, 45-min duration) on gently sloping burnt and unburnt woodlands similar to those in the present study.

\section{Data analysis}

Statistical analyses were restricted to within-site comparisons except where explicitly stated. Data collected at the small-plot scale were analysed using a split-plot mixed model. The wholeplot (treatment) factor had two levels, burnt and unburnt, and the subplot factor (microsite) had three levels: interspace, shrub coppice and tree coppice. Large-plot data were analysed using a split-plot mixed model with two treatment levels, burnt and unburnt, and two microsite levels, shrub-interspace zone and tree zone. Hillslope-scale data collected from site characterisation plots were analysed using a repeated-measures mixedmodel (compound symmetry covariance structure) with two treatment levels, burnt and unburnt, and sample year as the repeated measure, Year 0 and Year 1. Site, treatment and microsite were considered fixed effects in all respective analyses and plot location was designated a random effect. Prior to ANOVA, normality and homogeneity were tested using the Shapiro-Wilk test and Levene's test (SAS Institute 2008) and deviance from normality was addressed by data transformation. Back-transformed results are reported. Mean separation $(P<0.05)$ was conducted using the LSMEANS (SAS Institute 2008) procedure with Tukey's adjustment.

\section{Results}

\section{Small-plot scale}

Burning generated uniform bare conditions for shrub and interspace small-plot microsites that comprise the intercanopy at both sites. Total canopy and shrub canopy covers were reduced by burning on shrub plots at both sites (Table 2). Grass canopy cover on shrub and interspace plots was reduced by a factor of two to three following burning at Marking Corral, but was unaltered by burning on sparsely vegetated shrub and interspace plots at Onaqui (Table 2). Burning significantly reduced litter and basal plant cover and increased bare soil on shrub coppices at both sites, yielding bare ground (bare soil, rock, ash) of $65-75 \%$ across all burnt shrub plots. Bare ground in interspaces was 70-90\% across burnt and unburnt conditions (Table 2). Litter thickness underneath trees was reduced from $40 \mathrm{~mm}$ pre-fire to $23 \mathrm{~mm}$ post-fire at Marking Corral, and was similar for burnt conditions across both sites $(\sim 20 \mathrm{~mm})$. 
Percentage litter cover directly underneath trees was also reduced by burning at Marking Corral, but litter cover underneath trees averaged $75-80 \%$ post-fire across both sites (Table 2). The persistence of more than $70 \%$ litter cover at both sites was aided in part by tree needle cast during the first year post-fire. For burnt and unburnt treatments, the ground surface on tree plots was well protected from raindrop impact owing to $75 \%$ or more coverage of plant and litter material. In contrast, interspaces were largely bare across both treatments, and the ground surface on shrub coppices was marginally protected for the unburnt condition solely.

The bare interspaces were a primary source for runoff generation and sediment delivery across treatments and sites, and microsite hydrologic and erosion responses across sites were differently affected by burning. All interspace plots generated runoff and sediment regardless of the treatment or site (Table 3). Only two of the unburnt shrub plots and none of the unburnt tree plots at Marking Corral generated runoff. In contrast, $75-100 \%$ of tree and shrub plots at Onaqui generated runoff and sediment for the unburnt condition. Fire removal of vegetation and ground cover on shrub and interspace plots at Marking Corral had no effect on small-plot runoff or erosion, but erodibility at that site was low based on uniformly low sedimentto-runoff ratios (Table 3). Nearly $90 \%$ of burnt tree plots at Marking Corral produced runoff, generating more than $20 \mathrm{~mm}$ of runoff and nearly $50 \mathrm{~g} \mathrm{~m}^{-2}$ of sediment. Soils underneath tree litter at Marking Corral were strongly water repellent pre- and post-fire (Fig. 1a). Increased runoff post-fire on tree plots at Marking Corral occurred due to litter depth reduction (loss of rainfall storage, Table 2) and persistence of strongly waterrepellent soils post-fire (Fig. 1a). Nearly all of the tree plots at Onaqui generated runoff and erosion (Table 3), but litter cover and strong soil water repellency were consistent across burnt and unburnt tree plots at that site (Table 2, Fig. 1b). In contrast to the relatively minor interspace erosion $\left(\sim 20-40 \mathrm{~g} \mathrm{~m}^{-2}\right)$ at Marking Corral, burnt and unburnt interspaces at Onaqui generated $\sim 200-350 \mathrm{~g} \mathrm{~m}^{-2}$ of sediment and exhibited high erodibility, $5.53-7.11 \mathrm{~g} \mathrm{~m}^{-2}$ per mm of runoff. Overall, burning had no effect on small-plot runoff at Onaqui, but burning increased erosion by factors of three to six for shrub and tree plots (Table 3). Pre-fire, interspaces at Onaqui were the primary contributor of sediment, but all microsites generated substantial erosion following burning.

\section{Large-plot scale}

Burning enhanced bare-ground connectivity on large plots at both sites (Table 4). Prior to burning, the ground surface at the sites was primarily exposed bare soil and rock $(\sim 70-85 \%$ bare ground) in shrub-interspace zones and litter-covered in tree zones $(\sim 80-90 \%$ litter cover). Pre-fire understorey vegetation in shrub-interspaces was dominated by shrubs at Marking Corral (21\% shrub canopy) and by herbaceous plants at Onaqui (10\% grass and forbs; Table 4$)$. Ground cover by plants and litter pre-fire in shrub-interspace plots was less than 30\% at Marking Corral and less than $10 \%$ at Onaqui. Burning facilitated forb production in shrub-interspace plots at Marking Corral, but resulted in a significant decrease in total canopy cover owing to shrub consumption by fire (Table 4). Fire reduction of litter and

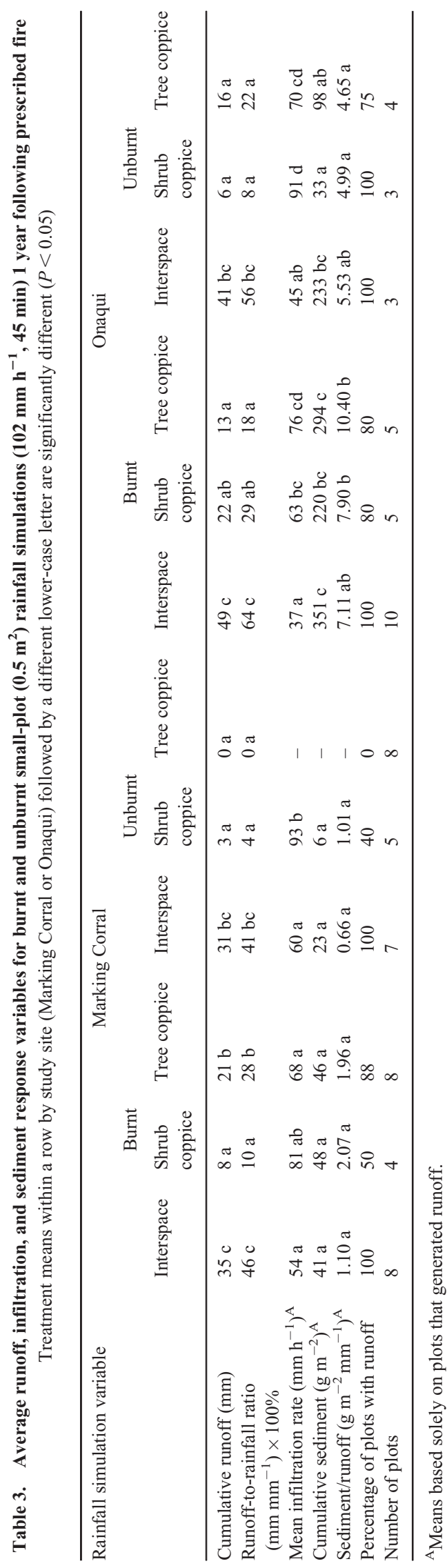


(a)

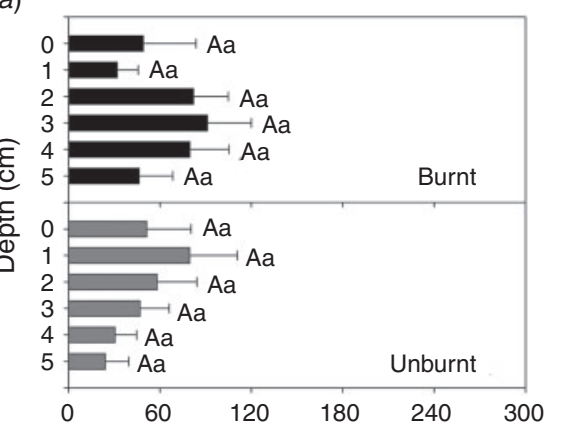

(b)

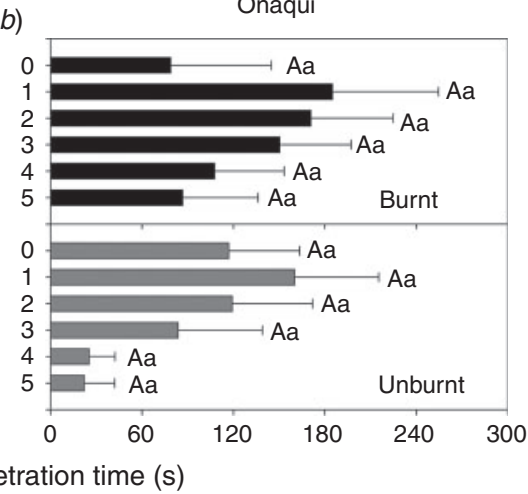

Fig. 1. Water drop penetration times (WDPT, 300-s maximum) measured at 0-5-cm soil depths underneath tree canopies on burnt and unburnt small rainfall simulation plots $\left(0.5 \mathrm{~m}^{2}\right)$ at the Marking Corral $(a)$, and Onaqui $(b)$ study sites 1 year post-fire. Soils were considered slightly water repellent if WDPT ranged from 5 to $60 \mathrm{~s}$ and strongly water repellent if WDPT exceeded $60 \mathrm{~s}$ (Bisdom et al. 1993). Error bars depict standard error. Site means across depths within a treatment followed by a different upper-case letter are significantly different $(P<0.05)$. Site means for a specific soil depth across treatments followed by a lower-case letter are significantly different $(P<0.05)$.

Table 4. Average surface roughness and canopy and ground cover measured on burnt (1 year post-fire) and unburnt (1 year before burning) large rainfall simulation plots $\left(13 \mathrm{~m}^{2}\right)$ at the Marking Corral and Onaqui study sites

Treatment means within a row by study site (Marking Corral or Onaqui) followed by a different lower-case letter are significantly different $(P<0.05)$

\begin{tabular}{|c|c|c|c|c|c|c|c|c|}
\hline \multirow[t]{3}{*}{ Plot characteristic } & \multicolumn{4}{|c|}{ Marking Corral } & \multicolumn{4}{|c|}{ Onaqui } \\
\hline & \multicolumn{2}{|l|}{ Burnt } & \multicolumn{2}{|c|}{ Unburnt } & \multicolumn{2}{|l|}{ Burnt } & \multicolumn{2}{|c|}{ Unburnt } \\
\hline & $\begin{array}{c}\text { Shrub-interspace } \\
\text { zone }\end{array}$ & Tree zone & $\begin{array}{l}\text { Shrub-interspace } \\
\text { zone }\end{array}$ & Tree zone & $\begin{array}{l}\text { Shrub-interspace } \\
\text { zone }\end{array}$ & Tree zone & $\begin{array}{l}\text { Shrub-interspace } \\
\text { zone }\end{array}$ & Tree zone \\
\hline Surface roughness (mm) & $15 \mathrm{a}$ & $13 \mathrm{a}$ & $17 \mathrm{ab}$ & $22 \mathrm{~b}$ & $26 \mathrm{a}$ & $26 \mathrm{a}$ & $31 \mathrm{a}$ & $35 \mathrm{a}$ \\
\hline Total canopy cover $(\%)^{\mathrm{A}}$ & $23.0 \mathrm{~b}$ & $6.2 \mathrm{a}$ & $34.7 \mathrm{c}$ & $15.9 \mathrm{~b}$ & $17.2 \mathrm{~b}$ & $3.3 \mathrm{a}$ & $12.7 \mathrm{a}$ & $20.8 \mathrm{~b}$ \\
\hline Shrub canopy cover $(\%)$ & $0.4 \mathrm{a}$ & $0.0 \mathrm{a}$ & $20.6 \mathrm{c}$ & $1.5 \mathrm{~b}$ & $0.2 \mathrm{a}$ & $0.1 \mathrm{a}$ & $0.5 \mathrm{~b}$ & $0.0 \mathrm{a}$ \\
\hline Grass canopy cover $(\%)$ & $5.1 \mathrm{bc}$ & $1.5 \mathrm{a}$ & $8.1 \mathrm{c}$ & $2.8 \mathrm{ab}$ & $6.1 \mathrm{~b}$ & $0.7 \mathrm{a}$ & $5.7 \mathrm{~b}$ & $12.3 \mathrm{c}$ \\
\hline Forb canopy cover $(\%)$ & $14.1 \mathrm{~b}$ & $4.2 \mathrm{a}$ & $0.4 \mathrm{a}$ & $0.2 \mathrm{a}$ & $1.8 \mathrm{a}$ & $0.5 \mathrm{a}$ & $4.7 \mathrm{~b}$ & $2.8 \mathrm{ab}$ \\
\hline $\begin{array}{l}\text { Plant and litter ground } \\
\text { cover }(\%)^{\mathrm{B}}\end{array}$ & $14.5 \mathrm{a}$ & $72.8 \mathrm{c}$ & $31.7 \mathrm{~b}$ & $93.6 \mathrm{~d}$ & $19.0 \mathrm{a}$ & $31.9 \mathrm{~b}$ & $15.8 \mathrm{a}$ & $88.2 \mathrm{c}$ \\
\hline Litter cover $(\%)$ & $10.4 \mathrm{a}$ & $66.9 \mathrm{c}$ & $28.5 \mathrm{~b}$ & $87.8 \mathrm{~d}$ & $15.1 \mathrm{a}$ & $30.1 \mathrm{~b}$ & $7.3 \mathrm{a}$ & $78.8 \mathrm{c}$ \\
\hline Rock cover $(\%)$ & $15.6 \mathrm{~b}$ & $3.6 \mathrm{a}$ & $46.8 \mathrm{c}$ & $3.6 \mathrm{a}$ & $38.1 \mathrm{~b}$ & $9.7 \mathrm{a}$ & $58.0 \mathrm{c}$ & $7.7 \mathrm{a}$ \\
\hline Bare soil (\%) & $69.7 \mathrm{c}$ & $18.9 \mathrm{~b}$ & $21.5 \mathrm{~b}$ & $2.8 \mathrm{a}$ & $42.7 \mathrm{c}$ & $41.0 \mathrm{c}$ & $26.1 \mathrm{~b}$ & $4.1 \mathrm{a}$ \\
\hline Ash (\%) & $0.2 \mathrm{a}$ & $4.8 \mathrm{~b}$ & - & - & $0.2 \mathrm{a}$ & $17.4 \mathrm{~b}$ & - & - \\
\hline Number of plots & 6 & 6 & 6 & 6 & 6 & 6 & 6 & 6 \\
\hline
\end{tabular}

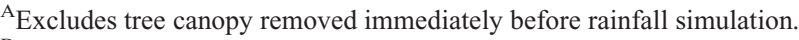

${ }^{\mathrm{B}}$ Includes cryptogam, litter, live and dead basal plant and woody dead cover.

basal plant cover in shrub-interspaces at Marking Corral increased bare ground (bare soil, rock, and ash) from 68 to $85 \%$. Burning had limited impact on the sparse canopy and ground cover in shrub-interspaces at Onaqui (Table 4). Bare ground averaged $82 \%$ across burnt and unburnt shrub-interspaces at that site. Burning affected tree zones through reduction of tree litter at both sites and grass cover at Onaqui (Table 4). The fires reduced tree-zone basal plant and litter cover by $22 \%$ at Marking Corral and by more than $60 \%$ at Onaqui (Table 4 ). Bare ground in burnt tree zones was 30\% at Marking Corral and was near $70 \%$ at Onaqui.

Runoff generated in well-connected bare interspaces contributed to four- to seven-fold differences in runoff and erosion rates from unburnt shrub-interspaces relative to tree zones, and erosion rates were amplified by burning (Figs 2 and 3). Approximately half of the rainfall applied in unburnt shrub-interspaces at a site became runoff(Table 5). The highly erodible bare surface in unburnt shrub-interspaces at Onaqui yielded five-fold more erosion than the well-protected ground surface in tree zones (Table 5). Erosion from unburnt shrub-interspaces at Marking Corral exceeded that of the tree zones (Table 5), but the magnitude of soil erosion was $60 \%$ less than that at Onaqui $(P<0.05)$. Overall, unburnt tree zones generated minor runoff and sediment discharge from the high-intensity simulated storms (Figs 2 and 3; Table 5). Burning had no significant effect on runoff at Marking Corral for the large-plot scale, but erosion at that site was more 


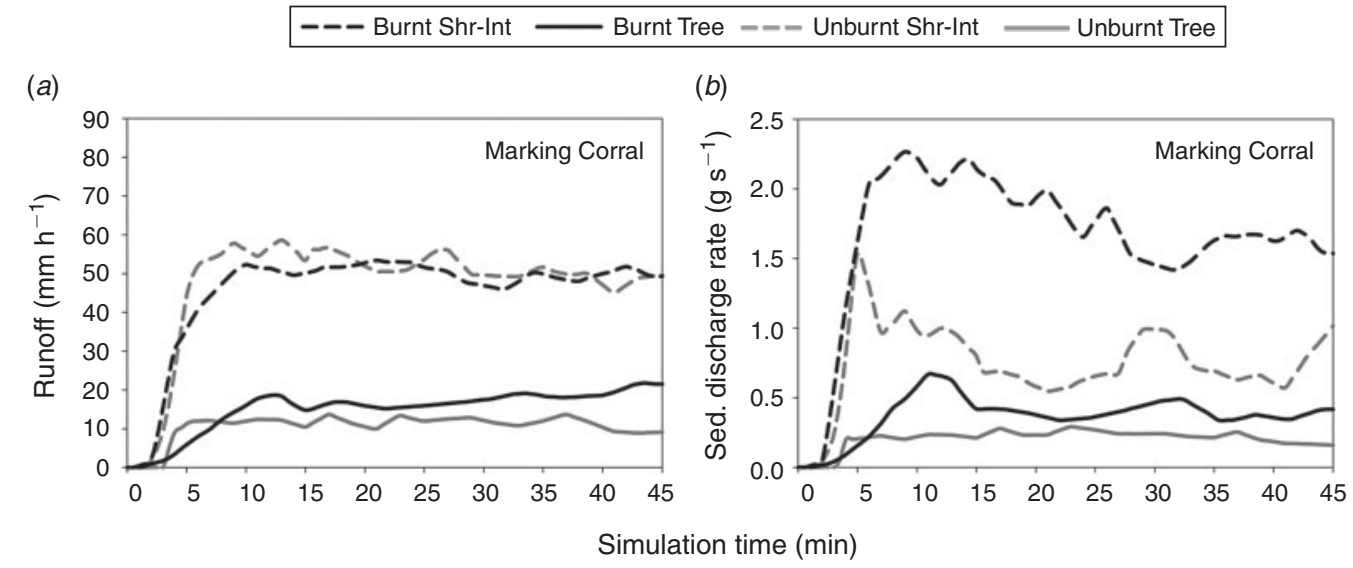

Fig. 2. Runoff hydrographs $(a)$ and sedigraphs $(b)$ for large-plot $\left(13 \mathrm{~m}^{2}\right)$ rainfall simulations $\left(102 \mathrm{~mm} \mathrm{~h}^{-1}, 45 \mathrm{~min}\right)$ that generated runoff on burnt (1 year post-fire) and unburnt (1 year pre-fire) tree (Tree; Pinus monophylla Torr. and Frém. or Juniperus osteosperma [Torr.] Little) and shrub-interspace (Shr-Int) zones at the Marking Corral study site.

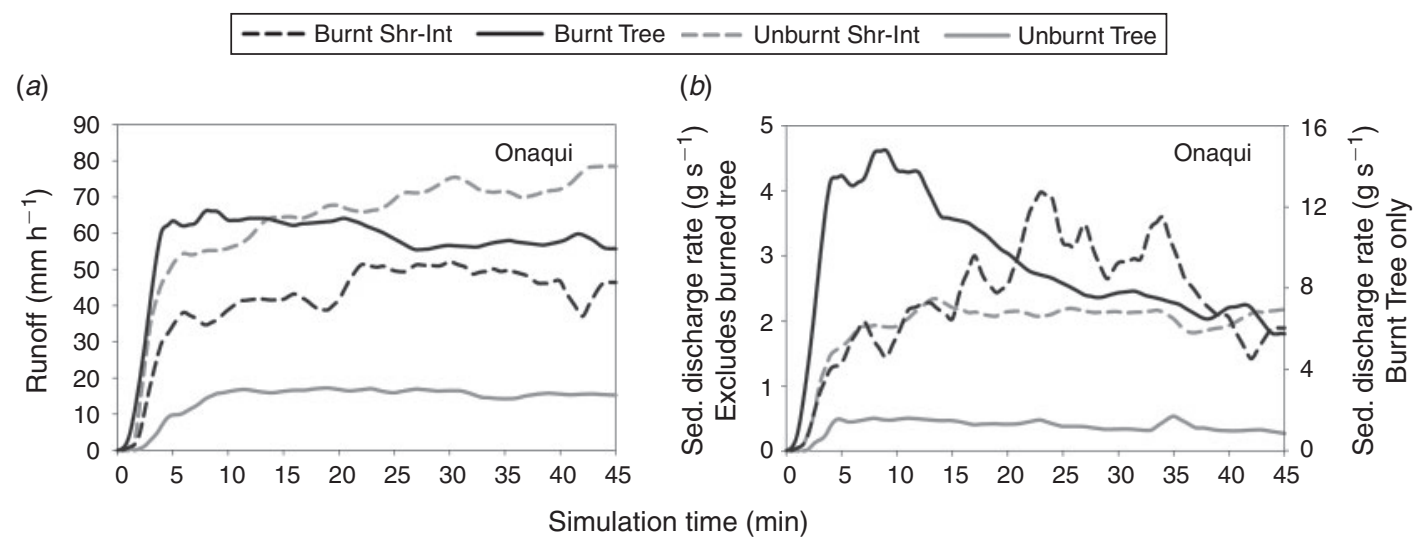

Fig. 3. Runoff hydrographs $(a)$, and sedigraphs $(b)$ for large-plot $\left(13 \mathrm{~m}^{2}\right)$ rainfall simulations $\left(102 \mathrm{~mm} \mathrm{~h}^{-1}, 45 \mathrm{~min}\right)$ that generated runoff on burnt ( 1 year post-fire) and unburnt (1 year pre-fire) shrub-interspace (Shr-Int) zones and tree zones (Tree; Juniperus osteosperma [Torr.] Little) at the Onaqui study site.

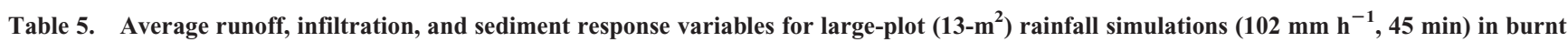
(1 year post-fire) and unburnt (1 year before burning) areas at the Marking Corral and Onaqui study sites

Treatment means within a row by study site (Marking Corral or Onaqui) followed by a different lower-case letter are significantly different $(P<0.05)$

\begin{tabular}{|c|c|c|c|c|c|c|c|c|}
\hline \multirow[t]{3}{*}{ Rainfall simulation variable } & \multicolumn{4}{|c|}{ Marking Corral } & \multicolumn{4}{|c|}{ Onaqui } \\
\hline & \multicolumn{2}{|c|}{ Burnt } & \multicolumn{2}{|c|}{ Unburnt } & \multicolumn{2}{|c|}{ Burnt } & \multicolumn{2}{|c|}{ Unburnt } \\
\hline & $\begin{array}{l}\text { Shrub- } \\
\text { interspace } \\
\text { zone }\end{array}$ & $\begin{array}{l}\text { Tree } \\
\text { zone }\end{array}$ & $\begin{array}{l}\text { Shrub- } \\
\text { interspace } \\
\text { zone }\end{array}$ & $\begin{array}{l}\text { Tree } \\
\text { zone }\end{array}$ & $\begin{array}{l}\text { Shrub- } \\
\text { interspace } \\
\text { zone }\end{array}$ & $\begin{array}{l}\text { Tree } \\
\text { zone }\end{array}$ & $\begin{array}{l}\text { Shrub- } \\
\text { interspace } \\
\text { zone }\end{array}$ & $\begin{array}{l}\text { Tree } \\
\text { zone }\end{array}$ \\
\hline Cumulative runoff $(\mathrm{mm})$ & $34 \mathrm{~b}$ & $11 \mathrm{a}$ & $36 \mathrm{~b}$ & $3 \mathrm{a}$ & $31 \mathrm{~b}$ & $43 \mathrm{~b}$ & $47 \mathrm{~b}$ & $11 \mathrm{a}$ \\
\hline Runoff-to-rainfall ratio $\left(\mathrm{mm} \mathrm{mm}^{-1}\right) \times 100 \%$ & $40 \mathrm{~b}$ & $13 \mathrm{a}$ & $46 \mathrm{~b}$ & $3 \mathrm{a}$ & $41 \mathrm{~b}$ & $52 \mathrm{~b}$ & $50 \mathrm{~b}$ & $12 \mathrm{a}$ \\
\hline Mean infiltration rate $\left(\mathrm{mm} \mathrm{h}^{-1}\right)^{\mathrm{A}}$ & $61 \mathrm{a}$ & $92 \mathrm{~b}$ & $57 \mathrm{a}$ & $115 \mathrm{~b}$ & $56 \mathrm{a}$ & $55 \mathrm{a}$ & $62 \mathrm{a}$ & $109 \mathrm{~b}$ \\
\hline Cumulative sediment $\left(\mathrm{g} \mathrm{m}^{-2}\right)^{\mathrm{A}}$ & $346 \mathrm{c}$ & $78 \mathrm{ab}$ & $154 \mathrm{~b}$ & $43 \mathrm{a}$ & $491 \mathrm{~b}$ & $1893 \mathrm{c}$ & $401 \mathrm{~b}$ & $78 \mathrm{a}$ \\
\hline Sediment/runoff $\left(\mathrm{g} \mathrm{m}^{-2} \mathrm{~mm}^{-1}\right)^{\mathrm{A}}$ & $9.56 \mathrm{a}$ & $7.15 \mathrm{a}$ & $4.21 \mathrm{a}$ & $5.40 \mathrm{a}$ & $16.01 \mathrm{c}$ & $44.67 \mathrm{~d}$ & $9.01 \mathrm{~b}$ & 6.09 \\
\hline Percentage of plots with runoff & 100 & 100 & 100 & 67 & 100 & 100 & 100 & 100 \\
\hline Number of plots & 6 & 6 & 6 & 6 & 5 & 5 & 6 & 6 \\
\hline
\end{tabular}

${ }^{\mathrm{A}}$ Mean based solely on plots that generated runoff. 

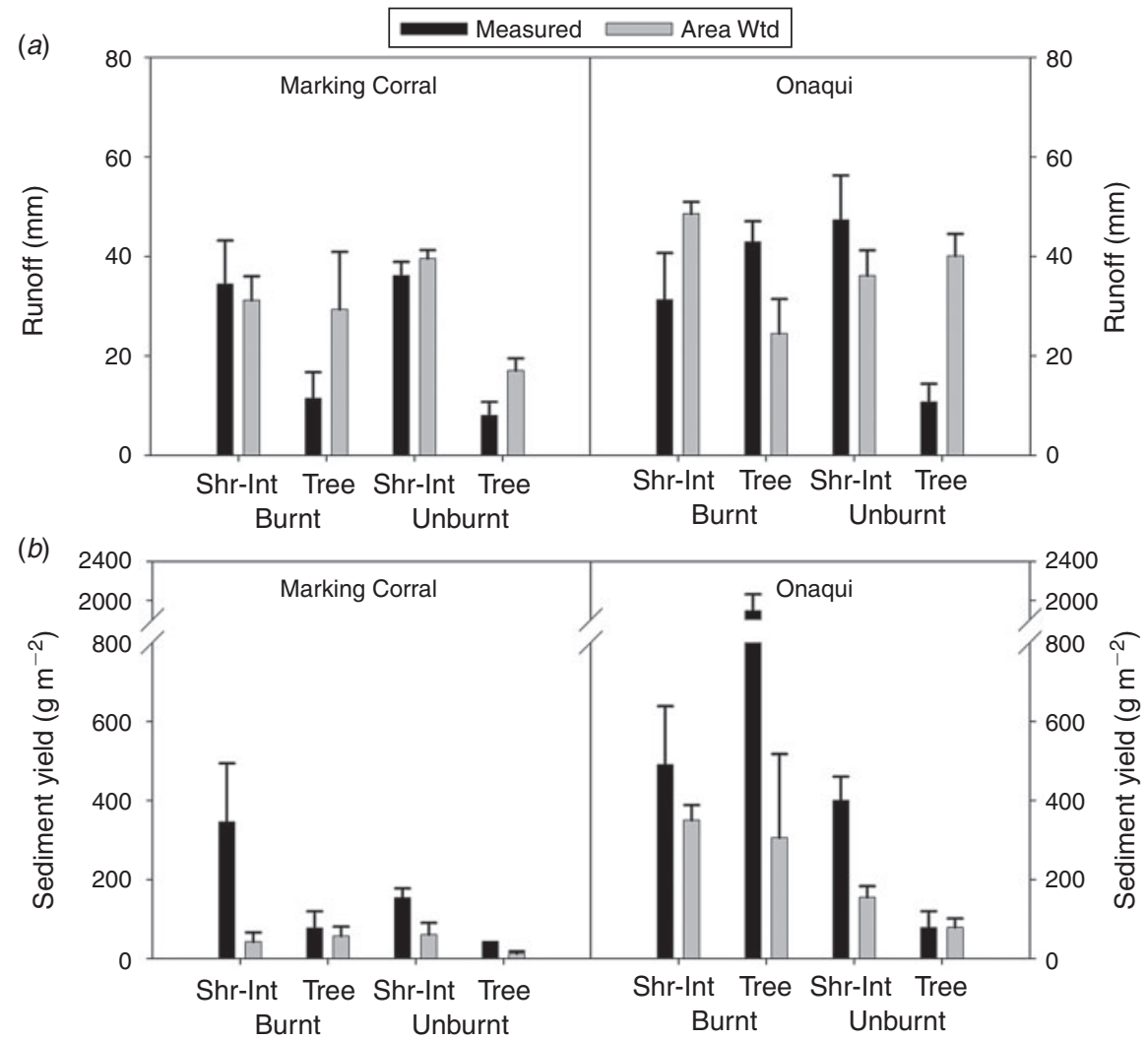

Fig. 4. Large-plot $\left(13 \mathrm{~m}^{2}\right)$ measured and microsite area-weighted cumulative runoff $(a)$, and sediment yield $(b)$ for rainfall simulations $\left(102 \mathrm{~mm} \mathrm{~h}^{-1}, 45 \mathrm{~min}\right.$ ) on burnt and unburnt shrub-interspace (ShrubInt) and tree (Tree; Pinus monophylla Torr. and Frém. or Juniperus osteosperma [Torr.] Little) zones at the Marking Corral and Onaqui study sites. Area-weighted large-plot runoff and erosion were determined by area-weighting burnt and unburnt tree coppice, shrub coppice and interspace small-plot $\left(0.5-\mathrm{m}^{2}\right)$ runoff and erosion rates into the $13-\mathrm{m}^{2}$ plots based on respective microsite area measured in unburnt shrub-interspace and tree zones. Error bars represent standard error.

than two-fold greater for burnt than unburnt shrub-interspace plots (Table 5). In contrast, burning resulted in similar runoff across burnt tree zones and all shrub-interspace plots at Onaqui (Table 5). Approximately $40-50 \%$ of rainfall applied to burnt tree zones and all shrub-interspace plots at Onaqui was converted to plot runoff (Table 5). Only $12 \%$ of rainfall was converted to runoff on unburnt tree zones at Onaqui. Fire removal of litter on tree zones at Onaqui dramatically increased sediment discharge (Fig. $3 b$ ) and resulted in 24-fold greater sediment yield and 7-fold more sediment per unit of runoff relative to unburnt tree zones. Soil erosion did not increase following burning of shrub-interspaces at Onaqui, but the amount of sediment per unit of runoff from shrub-interspace zones at the site increased by nearly $77 \%$ following fire (Table 5 ).

With few exceptions, runoff was generally similar across small-plot and large-plot scales for burnt and unburnt conditions (Fig. 4a). For the unburnt condition, sediment yield was consistent across spatial scales for areas underneath and influenced by tree canopies (Fig. 4b) owing to a preponderance of tree litter (Table 4). Sediment yield increased across small-plot to largeplot scales for unburnt shrub-interspaces without associated increases in cross-scale runoff(Fig. 4). The increase in sediment yield across spatial scales for unburnt shrub-interspaces at both sites is attributed to accentuated erosion and sediment transport in observed concentrated-flow paths within the sparsely vegetated shrub-interspace plots. Burning had no effect on cross-scale erosion from tree plots at Marking Corral due to accumulation of needle cast and limited spatial treelitter reduction (Tables 2 and 4). However, burning of shrubinterspaces at Marking Corral resulted in increased erosion across small-plot to large-plot scales without a cross-scale increase in runoff (Fig. 4). Erosion rates were high across the small-plot and large-plot scales for burnt shrub-interspaces at Onaqui (Fig. 4b). Sediment yield was more than six-fold greater for the measured large-plots than area-weighted large plots in burnt tree zones at Onaqui (Fig. 4b). The cross-scale fire effect on tree plots at Onaqui is attributed to ample sediment availability in tree zones following fire and formation of observed concentrated flow over burnt and water-repellent soils (Fig. 1b).

\section{Hillslope-scale}

The hillslope-scale plant community structure was coarse prefire, and bare ground was extensive before and after burning (Table 6). Prior to burning, $\sim 70 \%$ of the area at each site 
Table 6. Hillslope-scale understorey canopy and ground-cover characteristics pre- and post-fire as measured on $30 \times 33-\mathrm{m}$ site characterisation plots at the Marking Corral and Onaqui sites

Treatment means within a row followed by a different lower-case letter are significantly different $(P<0.05)$

\begin{tabular}{lrrrr}
\hline & \multicolumn{2}{c}{ Marking Corral } & \multicolumn{2}{c}{ Onaqui } \\
& Burnt & Unburnt $^{\mathrm{A}}$ & Burnt & Unburnt $^{\mathrm{A}}$ \\
& & & & \\
\hline Understorey canopy cover & & & & \\
Total canopy (\%) & $40.0 \mathrm{~b}$ & $26.8 \mathrm{ab}$ & $17.6 \mathrm{a}$ & $19.8 \mathrm{a}$ \\
Shrub (\%) & $4.6 \mathrm{~b}$ & $17.7 \mathrm{c}$ & $0.4 \mathrm{a}$ & $0.9 \mathrm{a}$ \\
Grass (\%) & $10.0 \mathrm{~b}$ & $4.8 \mathrm{ab}$ & $3.4 \mathrm{a}$ & $6.2 \mathrm{ab}$ \\
Forb (\%) & $10.6 \mathrm{c}$ & $0.1 \mathrm{a}$ & $6.0 \mathrm{bc}$ & $3.3 \mathrm{~b}$ \\
Ground cover & & & & \\
Basal plant (\%) & $0.1 \mathrm{a}$ & $0.3 \mathrm{a}$ & $0.4 \mathrm{a}$ & $0.9 \mathrm{a}$ \\
Moss and lichen (\%) & $0.0 \mathrm{a}$ & $0.0 \mathrm{a}$ & $2.4 \mathrm{ab}$ & $4.6 \mathrm{~b}$ \\
Litter (\%) & $31.4 \mathrm{a}$ & $47.4 \mathrm{~b}$ & $29.7 \mathrm{a}$ & $34.4 \mathrm{a}$ \\
Rock (\%) & $16.5 \mathrm{a}$ & $25.4 \mathrm{~b}$ & $31.6 \mathrm{~b}$ & $29.0 \mathrm{~b}$ \\
Bare soil (\%) & $52.0 \mathrm{~b}$ & $26.8 \mathrm{a}$ & $35.9 \mathrm{a}$ & $31.1 \mathrm{a}$ \\
\hline
\end{tabular}

${ }^{A}$ Data from Pierson et al. (2010), but restricted to the area subsequently burned as part of the present study.

${ }^{\mathrm{B}}$ Includes juvenile tree cover $(<1.0 \mathrm{~m}$ height, $<2 \%)$.

${ }^{\mathrm{C}}$ Includes trace amount of ash $(<1 \%)$.

comprised degraded intercanopy surrounding isolated 4- to 5-mdiameter litter-covered tree islands (25-30\% total tree cover). The Marking Corral site contained isolated shrub islands $(18 \%$ cover) within the intercanopy, surrounded by more than $50 \%$ bare ground (bare soil and rock). The understorey at Onaqui was sparsely vegetated with grass and forbs $(10 \%$ total herbaceous cover) pre-fire and contained $\sim 60 \%$ bare ground. Burning significantly reduced hillslope-scale shrub canopy and litter ground cover at Marking Corral (Table 6). Burning had no significant impact on the sparse understorey vegetation and ground cover at Onaqui over the hillslope scale (Table 6). Bare ground at both sites was near $70 \% 1$ year following the prescribed fires.

The effects of concentrated flow on the detachment and delivery of sediment from plot to hillslope scales are evident in the RHEM hillslope simulations for the degraded and burnt woodlands. RHEM simulations of 30-m hillslope runoff and erosion using the splash-sheet-dominated parameterisation generated low levels of erosion $\left(<40 \mathrm{~g} \mathrm{~m}^{-2}\right)$ for burnt and unburnt conditions regardless of the runoff event (Figs $5 a-c$ and $6 a-c$ ). Return-interval event simulations for the concentrated-flowdominated parameterisation (Figs $5 d$ and $6 d$ ) generated 5-15-fold more sediment than simulations with splash-sheet-dominated erosion (Figs $5 c$ and $6 c$ ) from burnt and unburnt conditions. For unburnt conditions at Marking Corral, the 25- to 100-year runoff events all generated fairly high levels of erosion $\left(>75 \mathrm{~g} \mathrm{~m}^{-2}\right)$ associated with connected splash-sheet and concentrated-flow processes (Fig. 5d). Modelling the 25-100-year runoff events for unburnt conditions with the splash-sheetdominated model generated $<15 \mathrm{~g} \mathrm{~m}^{-2}$ erosion for each event. The influence of process connectivity on simulated erosion was most evident for the burnt condition at Marking Corral. All simulated runoff events except the 2-year event generated more than $100 \mathrm{~g} \mathrm{~m}^{-2}$ from combined processes for the burnt condition at that site (Fig. $5 d$ ). The effects of sparse cover on runoff and

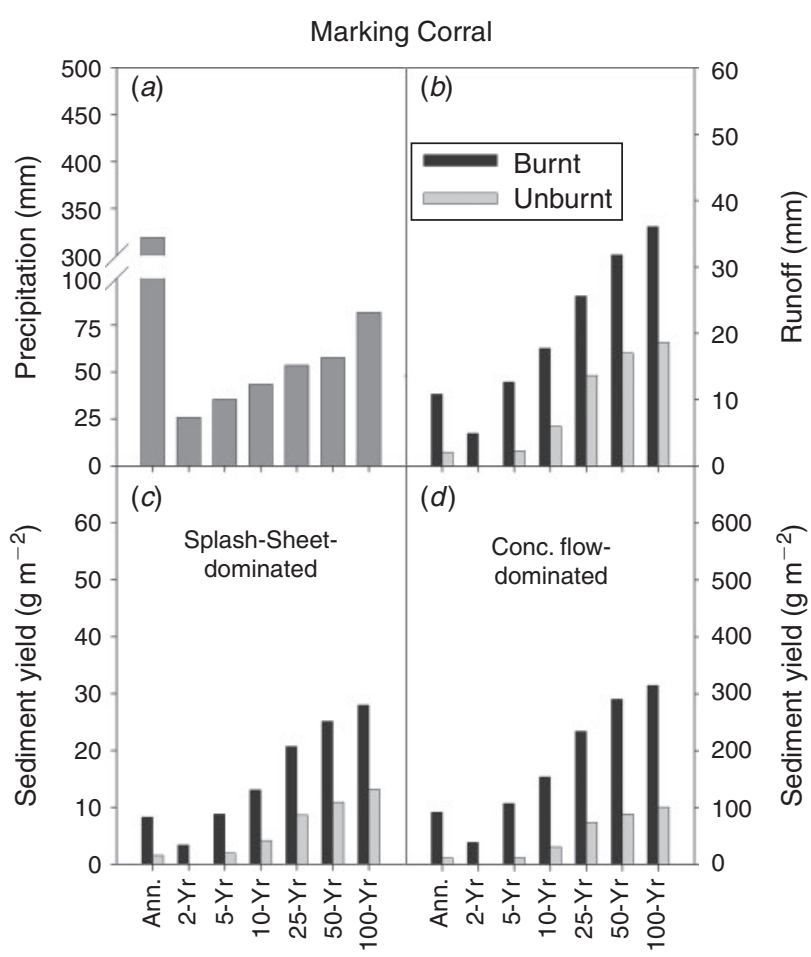

Fig. 5. Annual (Ann.) and runoff-event precipitation (a), and hillslopescale (30-m length) runoff $(b)$, and erosion $(c$ and $d$ ) predicted by the Rangeland Hydrology and Erosion Model (RHEM; Nearing et al. 2011; Al-Hamdan et al. 2015) for burnt (black bars) and unburnt (light-grey bars) conditions at Marking Corral. Predicted sediment yield is shown for cases in which erosion is dominated by splash and sheet ( $c$, left $y$ axis) and by concentrated-flow ( $d$, right $y$ axis) processes to demonstrate the effects of process connectivity on hillslope sediment delivery.

erodibility are evident for burnt and unburnt conditions at Onaqui. Differences in predicted runoff and sediment yield for burnt versus unburnt conditions at Onaqui (Fig. 6) were generally less than those observed for Marking Corral (Fig. 5). As with Marking Corral, the concentrated-flow-dominated parameterisation generated substantial erosion across burnt and unburnt conditions, with erosion $>100 \mathrm{~g} \mathrm{~m}^{-2}$ for nearly all return-interval events.

\section{Discussion}

The measured and modelled runoff responses across spatial scales for unburnt conditions demonstrate the effect of structural and functional connectivity on hillslope-scale hydrologic response. Bare interspaces between tree and shrub canopies were sources for runoff and sediment delivery at the patch scale. Modelled hillslope-scale runoff from the 100 -year event (19 mm runoff, $75 \mathrm{~mm}$ precipitation) on unburnt conditions at Marking Corral (Fig. $5 b$ ) was slightly less than that measured from largeplot rainfall simulations ( $\sim 27 \mathrm{~mm}$ area-weighted, Table 5). At Onaqui, modelled hillslope-scale runoff ( $35 \mathrm{~mm}$, Fig. $6 b)$ and measured large-plot runoff ( $\sim 37 \mathrm{~mm}$ area-weighted, Table 5) were similar for the 100 -year runoff event ( $75 \mathrm{~mm}$ precipitation). The differing cross-scale runoff responses for the sites are attributed to site differences in ground cover by litter (Table 6). 


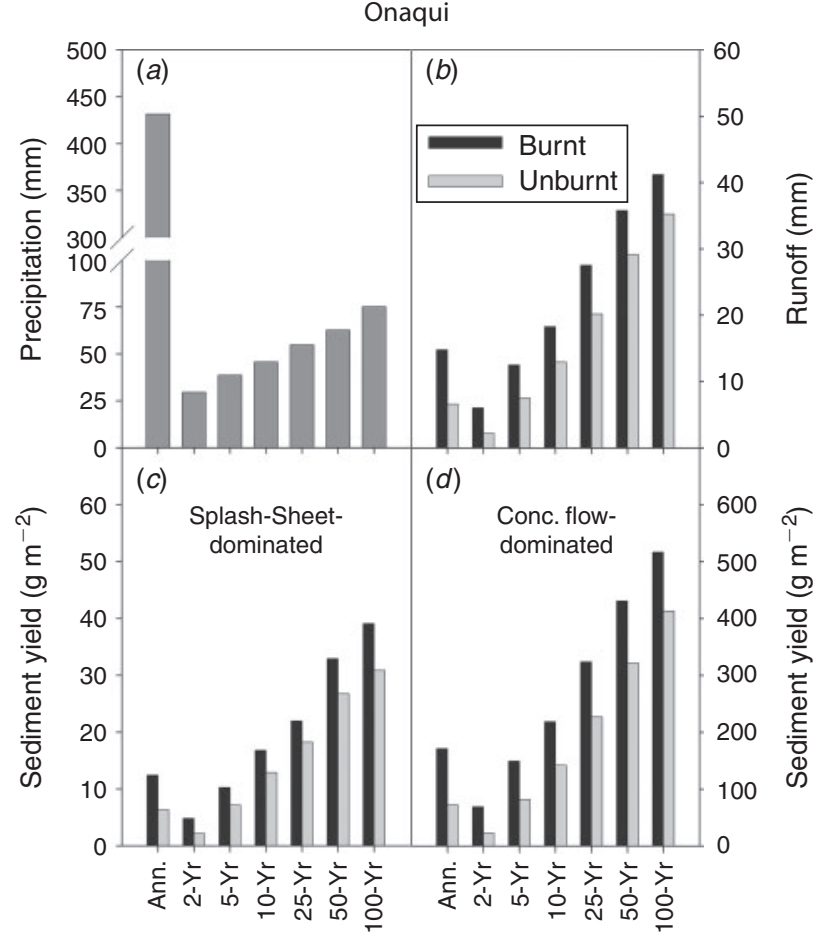

Fig. 6. Annual (Ann.) and runoff-event precipitation $(a)$, and hillslopescale (30-m length) runoff $(b)$, and erosion $(c$ and $d$ ) predicted by the Rangeland Hydrology and Erosion Model (RHEM; Nearing et al. 2011; Al-Hamdan et al. 2015) for burnt (black bars) and unburnt (light-grey bars) conditions at Onaqui. Predicted sediment yield is shown for cases in which erosion is dominated by splash and sheet ( $c$, left $y$ axis) and by concentrated-flow ( $d$, right $y$ axis) processes to demonstrate the effects of process connectivity on hillslope sediment delivery.

The limited attenuation in runoff across spatial scales is an indicator of low cross-scale run-on infiltration potential, wellconnected runoff sources and high sediment transport capacity at the hillslope scale (Puigdefábregas et al. 1999; Cammeraat 2002; Wainwright and Parsons 2002; Wilcox et al. 2003). The overall poor hydrologic function at the hillslope scale at both sites is the result of cross-scale structural connectivity of intercanopy bare ground and runoff sources (Davenport et al. 1998; Turnbull et al. 2008; Pierson et al. 2010; Turnbull et al. 2010a, 2010b; Reaney et al. 2014; Williams et al. 2014a).

Burning enhanced hillslope-scale structural connectivity of runoff sources and increased potential for cross-scale sediment transport. Burning at Marking Corral increased intercanopy bare ground, but had more limited impact on tree-zone bare ground owing to tree needle cast (Table 4). Measured runoff was consistent across plot scales for burnt conditions at Marking Corral (Fig. 4a) and was similar for burnt and unburnt conditions on large plots (Fig. 2a). However, modelled hillslope runoff for the 100-year event on burnt conditions at Marking $(36 \mathrm{~mm})$ was nearly twice that of unburnt conditions ( $19 \mathrm{~mm}$, Fig. $5 b)$ and was higher than measured for similar rainfall at the large-plot scale (Table 5). The greater hillslope-scale modelled runoff at Marking Corral for burnt versus unburnt conditions is attributed to increased cross-scale connectivity of bare ground (structural connectivity) following burning (Johansen et al. 2001;
Benavides-Solorio and MacDonald 2005; Wagenbrenner et al. 2006; Pierson et al. 2009; Williams et al. 2014a, 2014b). Bare ground was greater for burnt versus unburnt conditions at the hillslope scale at Marking Corral (Table 6) due to an increasing effect of large-plot litter coverage reductions (Table 4) aggregated over the larger spatial scale. At Onaqui, burning did not significantly reduce intercanopy ground cover at the large-plot scale, but did reduce tree-zone litter cover more than two-fold (Table 4). The limited ground-cover reductions in the intercanopy did not significantly affect large-plot runoff, but litter removal on strongly water-repellent soils under trees increased measured large-plot runoff by a factor of four (Table 5, Fig. 3). Runoff slightly increased across the small-plot to large-plot scales for tree plots at Onaqui following burning, a reversal of the pre-fire trend (Fig. 4a). Likewise, the 100-year-event modelled hillslopescale runoff for burnt conditions $(41 \mathrm{~mm})$ at the site was slightly greater than for unburnt conditions (35 mm, Fig. 6b) and was more than measured on burnt large plots $(34 \mathrm{~mm}$, area-weighted, Table 5). For both sites, the increased runoff across spatial scales for burnt conditions indicates that ample runoff was available for overland flow detachment and transport of soil particles to the hillslope scale (Wilcox et al. 1996; Robichaud et al. 2008a; Pierson et al. 2009; Robichaud et al. 2013b).

Erosion from rainfall simulations demonstrates the combined effect of process connectivity and sediment availability on patchscale soil erosion. At the small-plot scale, measured erosion from well-protected unburnt shrub plots was minimal (Table 3). The high-intensity storm applied to unburnt bare interspaces generated substantial erosion at Onaqui, but only limited erosion at Marking Corral (Table 3). However, measured erosion increased across small-plot to large-plot scales for the unburnt intercanopy at both sites without increases in cross-scale runoff (Fig. 4). Ample small-plot measured runoff generated in unburnt interspaces at both sites contributed to formation of concentrated-flow paths through the degraded shrub-interspace zones. The concentrated flow was able to transport rainsplash-detached sediment and to detach and transport sediment from within incised flow paths, yielding high rates of sediment discharge (Figs $2 b$ and $3 b$; Pierson et al. 2010, 2013; Williams et al. 2014b). Fire reductions of ground cover increased sediment availability on shrub and tree plots (Table 3; Pierson et al. 2002, 2008a, 2009; Robichaud et al. 2008b; Al-Hamdan et al. 2012a) and provided additional sediment for transport to large-plot scale (Pierson et al. 2009, 2013; Nyman et al. 2013; Williams et al. 2014b). Measured erosion increased across small-plot to large-plot scales for all burnt conditions except tree zones at Marking Corral (Fig. 4b). We attribute the increased cross-scale erosion for burnt plots to connectivity of runoff, similar to unburnt conditions, and additional sediment availability from burnt tree and shrub coppice areas. Erosion did not increase following burning of tree zones at Marking Corral due to the surface protection by needle cast (Pannkuk and Robichaud 2003) and limited runoff (Fig. 2a).

The RHEM hillslope simulations further demonstrate the combined effect of cross-scale process connectivity and sediment availability on hillslope-scale response. The splash-sheetdominated simulations predicted minor sediment yield at the hillslope scale for unburnt and burnt conditions (Figs $5 c$ and $6 c$ ). For the 100-year runoff event at Marking Corral, the concentrated-flow-dominated model predicted 100 and $314 \mathrm{~g} \mathrm{~m}^{-2}$ 
sediment yield for unburnt and burnt conditions respectively. The 100-year event sediment yields predicted for Marking Corral (Fig. $5 d$ ) were nearly equal to those measured on unburnt and burnt large plots (124 and $274 \mathrm{~g} \mathrm{~m}^{-2}$ area-weighted) with a similar total rainfall ( $\sim 80 \mathrm{~mm})$. At Onaqui, the 100-year event with the concentrated-flow-dominated model predicted 413 and $516 \mathrm{~g} \mathrm{~m}^{-2}$ for unburnt and burnt conditions respectively. The RHEM 100-year event sediment yields predicted for Onaqui (Fig. 6d) exceeded that measured on large plots for unburnt conditions (311 $\mathrm{g} \mathrm{m}^{-2}$ area-weighted) and were less than measured on large plots for burnt conditions $\left(884 \mathrm{~g} \mathrm{~m}^{-2}\right.$ areaweighted). The RHEM results for Onaqui suggest sediment availability at the large-plot scale may have been greater than at the hillslope scale for burnt conditions. Al-Hamdan et al. (2012a) derived stream-power-based erodibilities for the Onaqui site using data from concentrated-flow experiments in this study and reported erodibilities of $4.03 \times 10^{-3}$ and $0.66 \times 10^{-3} \mathrm{~s}^{2} \mathrm{~m}^{-2}$ for burnt tree zones and shrub-interspace zones respectively. Area-weighting those values for the tree and shrub-interspace zones at Onaqui yields an estimated erodibility of $3.09 \times 10^{-3} \mathrm{~s}^{2} \mathrm{~m}^{-2}$, a value substantially greater than the cover-based stream power erodibility $1.067 \times 10^{-3} \mathrm{~s}^{2} \mathrm{~m}^{-2}$ $\left(K_{\omega(\max )}\right.$, Eqn 4) derived for RHEM simulations of burnt conditions at Onaqui. For both sites, burning increased sediment availability at all scales of measurement through reduction of surface protection in the few areas of pre-fire soil accumulation (Robichaud et al. 2008b; Al-Hamdan et al. 2012a; Nyman et al. 2013; Williams et al. 2014b). The large differences in erosion across burnt and unburnt conditions for the two sites are attributed to inherent site-specific differences in soil erodibility (Pierson et al. 2010; Al-Hamdan et al. 2012a) and overall more degraded conditions and higher runoff (unburnt condition) at Onaqui.

Our results in context with other studies underscore the importance of considering the connectivity of surface susceptibility (structural connectivity) and rainfall characteristics in prediction of burnt area hydrologic and erosion responses (Moody and Martin 2001b; Reaney et al. 2007; Moody et al. 2008, 2013; Robichaud et al. 2013b; Wagenbrenner and Robichaud 2013; Williams et al. 2014a). Our single-intensity plot-scale results demonstrate that hillslope-scale responses to rainfall input are dictated by the connectivity of hydrologically susceptible surface conditions and the integration of runoff and erosion processes (functional connectivity) across spatial scales. Surface conditions and topography affect runoff and erosion at various scales largely by affecting the amount and energy of water input and storage (Benavides-Solorio and MacDonald 2005; Wagenbrenner et al. 2006; Reaney et al. 2007; Moody et al. 2008; Pierson et al. 2009; Al-Hamdan et al. 2012 b, 2013; Wagenbrenner and Robichaud 2013; Reaney et al. 2014; Williams et al. 2014a, 2014b). The amount and energy of water applied to the overall system is of course governed by the rainfall characteristics (i.e. amount, mass, intensity). For conditions in the present study, application of a varying-intensity event or one with a higher or lower intensity and duration would likely elicit different plot-scale runoff and erosion responses (Wainwright and Parsons 2002), as illustrated by the RHEM modelled return-interval runoff events (Figs 5 and 6 ). Numerous studies have documented the effect of rainfall characteristics on runoff and erosion responses (Benavides-Solorio and
MacDonald 2005; Spigel and Robichaud 2007; Cannon et al. 2008, 2011; Robichaud et al. 2013b; Moody et al. 2013). In each of these studies, the largest events were associated with high volumes of water input, contiguous susceptible surface conditions, and connectivity of processes across spatial scales.

\section{Conclusions}

Our results clearly demonstrate the roles of structural and functional connectivity in the delivery of hillslope-scale runoff and sediment for degraded and burnt landscapes, and show that cross-scale runoff and sediment delivery evolve through the connectivity of susceptible surface conditions and superposition of overland flow and erosion processes. The magnitude of hydrologic response is governed by the degree of connectivity in processes, sediment availability, and the intensity and volume of water input. Degradation of arid and semiarid landscapes increases the structural connectivity of surface susceptibility to runoff generation and sediment detachment and transport. Runoff generated in bare patches concentrates downslope into defined flow paths with high velocity and sediment detachment and transport capacity. Burning increases structural and process connectivity and sediment availability through the removal of canopy and ground cover. Increased sediment availability results in a greater magnitude of cross-scale sediment yield where runoff and erosion processes are well connected across spatial scales. Of course, the magnitude of response is also strongly influenced by the intensity or volume of water input given erosion dependency on rainfall and runoff for sediment delivery. Although our inferences are drawn from only two study sites, the hydrologic and erosion responses at each spatial scale in this study are consistent with other studies from degraded and burnt landscapes and provide tangible evidence of the importance in considering cross-scale connectivity of surface susceptibility, runoff and erosion processes, and sediment availability when forecasting hillslope hydrologic response.

\section{Acknowledgements}

This manuscript results from a presentation at the American Geophysical Union Chapman Conference on Synthesising Empirical Results to Improve Predictions of Post-wildfire Runoff and Erosion Responses, Estes Park, Colorado, USA, 25-31 August 2013. The authors thank the conference conveners for organising the conference, inviting our presentation, and facilitating extensive discussion and synthesis on the state of knowledge regarding post-wildfire runoff and erosion research. This paper is Contribution Number 106 of the Sagebrush Steppe Treatment Evaluation Project (SageSTEP), funded by the US Joint Fire Science Program, the Bureau of Land Management and the National Interagency Fire Center. The authors also thank Patrick Kormos for supervision of field data collection and Jaime Calderon and Matthew Frisby for assistance with field data collection. The USDA is an equal opportunity provider and employer.

\section{References}

Abrahams AD, Parsons AJ, Wainwright J (1995) Effects of vegetation change on interrill runoff and erosion, Walnut Gulch, southern Arizona. Geomorphology 13, 37-48. doi:10.1016/0169-555X(95)00027-3

Al-Hamdan OZ, Pierson FB, Nearing MA, Williams CJ, Stone JJ, Kormos PR, Boll J, Weltz MA (2012a) Concentrated-flow erodibility for physically based erosion models: temporal variability in disturbed and undisturbed rangelands. Water Resources Research 48, W07504. doi:10.1029/2011WR011464 
Al-Hamdan OZ, Pierson FB, Nearing MA, Stone JJ, Williams CJ, Moffet CA, Kormos PR, Boll J, Weltz MA (2012b) Characteristics of concentrated-flow hydraulics for rangeland ecosystems: implications for hydrologic modeling. Earth Surface Processes and Landforms 37, 157-168. doi:10.1002/ESP.2227

Al-Hamdan OZ, Pierson FB, Nearing MA, Williams CJ, Stone JJ, Kormos PR, Boll J, Weltz MA (2013) Risk assessment of erosion from concentrated flow on rangelands using overland flow distribution and shear stress partitioning. Transactions of the ASABE 56, 539-548. doi:10.13031/2013.42684

Al-Hamdan OZ, Hernandez M, Pierson FB, Nearing MA, Williams CJ, Stone JJ, Boll J, Weltz MA (2015) Rangeland hydrology and erosion model (RHEM) enhancements for applications on disturbed rangelands. Hydrological Processes 29, 445-457. doi:10.1002/HYP.10167

Benavides-Solorio JDD, MacDonald LH (2005) Measurement and prediction of post-fire erosion at the hillslope scale, Colorado Front Range. International Journal of Wildland Fire 14, 457-474. doi:10.1071/ WF05042

Bisdom EBA, Dekker LW, Schoute JFT (1993) Water repellency of sieve fractions from sandy soils and relationships with organic material and soil structure. Geoderma 56, 105-118. doi:10.1016/0016-7061(93) 90103-R

Bracken LJ, Croke J (2007) The concept of hydrological connectivity and its contribution to understanding runoff-dominated geomorphic systems. Hydrological Processes 21, 1749-1763. doi:10.1002/HYP.6313

Bracken LJ, Wainwright J, Ali GA, Tetzlaff D, Smith MW, Reaney SM, Roy AG (2013) Concepts of hydrological connectivity: research approaches, pathways and future agendas. Earth-Science Reviews 119 17-34. doi:10.1016/J.EARSCIREV.2013.02.001

Cammeraat LH (2002) A review of two strongly contrasting geomorphological systems within the context of scale. Earth Surface Processes and Landforms 27, 1201-1222. doi:10.1002/ESP.421

Cannon SH, Powers PS, Savage WZ (1998) Fire-related hyperconcentrated and debris flows on Storm King Mountain, Glenwood Springs, Colorado, USA. Environmental Geology 35, 210-218. doi:10.1007/ S002540050307

Cannon SH, Bigio ER, Mine E (2001a) A process for fire-related debris flow initiation, Cerro Grande fire, New Mexico. Hydrological Processes 15, 3011-3023. doi:10.1002/HYP.388

Cannon SH, Kirkham RM, Parise M (2001b) Wildfire-related debris-flow initiation processes, Storm King Mountain, Colorado. Geomorphology 39, 171-188. doi:10.1016/S0169-555X(00)00108-2

Cannon SH, Gartner JE, Wilson RC, Bowers JC, Laber JL (2008) Storm rainfall conditions for floods and debris flows from recently burned areas in south-western Colorado and southern California. Geomorphology 96, 250-269. doi:10.1016/J.GEOMORPH.2007.03.019

Cannon SH, Boldt EM, Laber JL, Kean JW, Staley DM (2011) Rainfall intensity duration thresholds for post-fire debris-flow emergencyresponse planning. Natural Hazards 59, 209-236. doi:10.1007/ S11069-011-9747-2

Cantón Y, Solé-Benet A, de Vente J, Boix-Fayos C, Calvo-Cases A, Asensio C, Puigdefábregas J (2011) A review of runoff generation and soil erosion across scales in semiarid south-eastern Spain. Journal of Arid Environments 75, 1254-1261. doi:10.1016/J.JARIDENV.2011.03.004

Davenport DW, Breshears DD, Wilcox BP, Allen CD (1998) Viewpoint: Sustainability of piñon-juniper ecosystems - a unifying perspective of soil erosion thresholds. Journal of Range Management 51, 231-240. doi: $10.2307 / 4003212$

de Vente J, Poesen J (2005) Predicting soil erosion and sediment yield at the basin scale: scale issues and semi-quantitative models. Earth-Science Reviews 71, 95-125. doi:10.1016/J.EARSCIREV.2005.02.002

DeBano LF (1981) Water repellent soils: a state of the art. USDA Forest Service, Pacific Southwest Forest and Range Experiment Station, General Technical Report PSW-46. (Berkeley, CA)
Flanagan DC, Nearing MA (1995) USDA Water Erosion Prediction Project (WEPP) hillslope profile and watershed model documentation. USDA Agricultural Research Service, National Soil Erosion Research Laboratory, NSERL Report No. 10. (West Lafayette, IN)

Holland ME (1969) Colorado State University experimental rainfall-runoff facility, design and testing of a rainfall system. Colorado State University, Colorado State University Experimental Station, Report CER 69-70 MEH. (Fort Collins, CO)

Johansen MP, Hakonson TE, Breshears DD (2001) Post-fire runoff and erosion from rainfall simulation: contrasting forests with shrublands and grasslands. Hydrological Processes 15, 2953-2965. doi:10.1002/ HYP.384

Kutiel P, Lavee H, Segev M, Benyamini Y (1995) The effect of fireinduced surface heterogeneity on rainfall-runoff-erosion relationships in an eastern Mediterranean ecosystem, Israel. Catena 25, 77-87. doi:10.1016/0341-8162(94)00043-E

Ludwig J, Tongway D, Freudenberger D, Noble J, Hodgkinson K (1997) 'Landscape ecology: function and management - principles from Australia's rangelands.' (CSIRO: Melbourne)

Ludwig JA, Wilcox BP, Breshears DD, Tongway DJ, Imeson AC (2005) Vegetation patches and runoff-erosion as interacting ecohydrological processes in semiarid landscapes. Ecology 86, 288-297. doi:10.1890/ 03-0569

Moody JA, Martin DA (2001a) Initial hydrologic and geomorphic response following a wildfire in the Colorado Front Range. Earth Surface Processes and Landforms 26, 1049-1070. doi:10.1002/ESP.253

Moody JA, Martin DA (2001b) Post-fire, rainfall intensity-peak discharge relations for three mountainous watersheds in the western USA Hydrological Processes 15, 2981-2993. doi:10.1002/HYP.386

Moody JA, Martin DA, Haire SL, Kinner DA (2008) Linking runoff response to burn severity after a wildfire. Hydrological Processes 22, 2063-2074. doi:10.1002/HYP.6806

Moody JA, Shakesby RA, Robichaud PR, Cannon SH, Martin DA (2013) Current research issues related to post-wildfire runoff and erosion processes. Earth-Science Reviews 122, 10-37. doi:10.1016/J.EAR SCIREV.2013.03.004

Natural Resources Conservation Service (NRCS) (2006) Soil Survey Geographic (SSURGO) database for Tooele Area, Utah - Tooele County and parts of Box Elder, Davis, and Juab Counties, Utah, White Pine and Elko Counties, Nevada. (USDA Natural Resources Conservation Service: Fort Worth, TX)

Natural Resources Conservation Service (NRCS) (2007) Soil Survey Geographic (SSURGO) database for Western White Pine County Area, Nevada, parts of White Pine and Eureka Counties. (USDA Natural Resources Conservation Service: Fort Worth, TX)

Nearing MA, Wei H, Stone JJ, Pierson FB, Spaeth KE, Weltz MA, Flanagan DC, Hernandez M (2011) A rangeland hydrology and erosion model. Transactions of the ASABE 54, 901-908. doi:10.13031/2013. 37115

Neary DG, Koestner KA, Youberg A, Koestner PE (2012) Post-fire rill and gully formation, Schultz Fire 2010, Arizona, USA. Geoderma 191, 97-104. doi:10.1016/J.GEODERMA.2012.01.016

Nyman P, Sheridan GJ, Moody JA, Smith HG, Noske PJ, Lane PNJ (2013) Sediment availability on burned hillslopes Journal of Geophysical Research: Earth Surface 118, 2451-2467.

Pannkuk CD, Robichaud PR (2003) Effectiveness of needle cast at reducing erosion after forest fires. Water Resources Research 39, 1333 doi:10.1029/2003WR002318

Parsons A, Robichaud PR, Lewis SA, Napper C, Clark JT (2010) Field guide for mapping post-fire soil burn severity. USDA Forest Service, Rocky Mountain Research Station, General Technical Report, RMRS-GTR243. (Fort Collins, CO)

Pierson FB, Jr, Van Vactor SS, Blackburn WH, Wood JC (1994) Incorporating small-scale spatial variability into predictions of hydrologic 
response on sagebrush rangelands. In 'Variability in rangeland water erosion processes', Soil Science Society of America Special Publication 38. pp. 23-24. (Soil Science Society of America: Madison, WI)

Pierson FB, Carlson DH, Spaeth KE (2002) Impacts of wildfire on soil hydrological properties of steep sagebrush-steppe rangeland. International Journal of Wildland Fire 11, 145-151. doi:10.1071/WF02037

Pierson FB, Robichaud PR, Moffet CA, Spaeth KE, Hardegree SP, Clark PE, Williams CJ (2008a) Fire effects on rangeland hydrology and erosion in a steep sagebrush-dominated landscape. Hydrological Processes 22, 2916-2929. doi:10.1002/HYP.6904

Pierson FB, Robichaud PR, Moffet CA, Spaeth KE, Williams CJ, Hardegree SP, Clark PE (2008b) Soil water repellency and infiltration in coarse-textured soils of burned and unburned sagebrush ecosystems. Catena 74, 98-108. doi:10.1016/J.CATENA.2008.03.011

Pierson FB, Moffet CA, Williams CJ, Hardegree SP, Clark PE (2009) Prescribed-fire effects on rill and interrill runoff and erosion in a mountainous sagebrush landscape. Earth Surface Processes and Landforms 34, 193-203. doi:10.1002/ESP.1703

Pierson FB, Williams CJ, Kormos PR, Hardegree SP, Clark PE, Rau BM (2010) Hydrologic vulnerability of sagebrush steppe following pinyon and juniper encroachment. Rangeland Ecology and Management 63, 614-629. doi:10.2111/REM-D-09-00148.1

Pierson FB, Williams CJ, Hardegree SP, Weltz MA, Stone JJ, Clark PE (2011) Fire, plant invasions, and erosion events on western rangelands. Rangeland Ecology and Management 64, 439-449. doi:10.2111/REMD-09-00147.1

Pierson FB, Williams CJ, Hardegree SP, Clark PE, Kormos PR, Al-Hamdan OZ (2013) Hydrologic and erosion responses of sagebrush steppe following juniper encroachment, wildfire, and tree cutting. Rangeland Ecology and Management 66, 274-289. doi:10.2111/REMD-12-00104.1

Pierson FB, Williams CJ, Kormos PR, Al-Hamdan OZ (2014) Short-term effects of tree removal on infiltration, runoff, and erosion in woodlandencroached sagebrush steppe Rangeland Ecology and Management 67, 522-538. doi:10.2111/REM-D-13-00033.1

Prism Group (2009) Prism Climate Group, Oregon State University. Available at: http://www.prism.oregonstate.edu/ [Verified 23 September 2009]

Puigdefábregas J (2005) The role of vegetation patterns in structuring runoff and sediment fluxes in drylands. Earth Surface Processes and Landforms 30, 133-147. doi:10.1002/ESP.1181

Puigdefábregas J, Sole A, Gutierrez L, Del Barrio G, Boer M (1999) Scales and processes of water and sediment redistribution in drylands: results from the Rambla Honda field site in south-east Spain. Earth-Science Reviews 48, 39-70. doi:10.1016/S0012-8252(99)00046-X

Reaney SM, Bracken LJ, Kirkby MJ (2007) Use of the Connectivity of Runoff Model (CRUM) to investigate the influence of storm characteristics on runoff generation and connectivity in semi-arid areas. Hydrological Processes 21, 894-906. doi:10.1002/HYP.6281

Reaney SM, Bracken LJ, Kirkby MJ (2014) The importance of surface controls on overland flow connectivity in semi-arid environments: results from a numerical experimental approach. Hydrological Processes 28, 2116-2128. doi:10.1002/HYP.9769

Robichaud PR, Elliot WJ, Pierson FB, Hall DE, Moffet CA (2007) Predicting post-fire erosion and mitigation effectiveness with a webbased probabilistic erosion model. Catena 71, 229-241. doi:10.1016/ J.CATENA.2007.03.003

Robichaud PR, Wagenbrenner JW, Brown RE, Wohlgemuth PM, Beyers JL (2008a) Evaluating the effectiveness of contour-felled log erosion barriers as a post-fire runoff and erosion mitigation treatment in the western United States. International Journal of Wildland Fire 17, 255-273. doi:10.1071/WF07032

Robichaud PR, Pierson FB, Brown RE, Wagenbrenner JW (2008b) Measuring effectiveness of three post-fire hillslope erosion barrier treatments, western Montana, USA. Hydrological Processes 22, 159-170. doi:10.1002/HYP.6558

Robichaud PR, Lewis SA, Wagenbrenner JW, Ashmun LE, Brown RE (2013a) Post-fire mulching for runoff and erosion mitigation. Part I: Effectiveness at reducing hillslope runoff erosion rates. Catena 105, 75-92. doi:10.1016/J.CATENA.2012.11.015

Robichaud PR, Wagenbrenner JW, Lewis SA, Ashmun LE, Brown RE, Wohlgemuth PM (2013b) Post-fire mulching for runoff and erosion mitigation. Part II: Effectiveness in reducing runoff and sediment yields from small catchments. Catena 105, 93-111. doi:10.1016/J.CATENA. 2012.11.016

SAS Institute (2008) 'SAS System software, release 9.2.' (SAS Institute Inc.: Cary, NC)

Shakesby RA, Doerr SH (2006) Wildfire as a hydrological and geomorphological agent. Earth-Science Reviews 74, 269-307. doi:10.1016/J.EAR SCIREV.2005.10.006

Shakesby RA, Doerr SH, Walsh RPD (2000) The erosional impact of soil hydrophobicity: current problems and future research directions. Journal of Hydrology 231-232, 178-191. doi:10.1016/S0022-1694(00)00193-1

Smith RE, Goodrich DC, Woolhiser DA, Unkrich CL (1995) KINEROS: A kinematic runoff and erosion model. In 'Computer models of watershed hydrology’. (Eds VJ Singh) Ch. 20, pp. 697-732. (Water Resources Publications: Highlands Ranch, CO)

Spigel KM, Robichaud PR (2007) First-year post-fire erosion rates in Bitterroot National Forest, Montana. Hydrological Processes 21, 998-1005. doi:10.1002/HYP.6295

Thornton PE, Thornton MM, Mayer BW, Wilhelmi N, Wei Y, Cook RB (2012) Daymet: daily surface weather on a 1-km grid for North America,1980-2011. Oak Ridge National Laboratory Distributed Active Archive Center. (Oak Ridge, TN) Available at http://daymet. ornl.gov/ [Verified 14 February 2013]. doi:10.3334/ORNLDAAC/ DAYMET_V2

Turnbull L, Wainwright J, Brazier RE (2008) A conceptual framework for understanding semi-arid land degradation: ecohydrological interactions across multiple space and time scales. Ecohydrology 1, 23-34. doi:10.1002/ECO.4

Turnbull L, Wainwright J, Brazier RE (2010a) Changes in hydrology and erosion over a transition from grassland to shrubland. Hydrological Processes 24, 393-414.

Turnbull L, Wainwright J, Brazier RE, Bol R (2010b) Biotic and abiotic changes in ecosystem structure over a shrub-encroachment gradient in the south-western USA. Ecosystems 13, 1239-1255. doi:10.1007/ S10021-010-9384-8

Wagenbrenner JW, Robichaud PR (2013) Post-fire bedload sediment delivery across spatial scales in the interior western United States. Earth Surface Processes and Landforms . doi:10.1002/ESP.3488

Wagenbrenner JW, MacDonald LH, Rough D (2006) Effectiveness of three post-fire rehabilitation treatments in the Colorado Front Range. Hydrological Processes 20, 2989-3006. doi:10.1002/HYP.6146

Wagenbrenner JW, Robichaud PR, Elliot WJ (2010) Rill erosion in natural and disturbed forests: 2. Modeling approaches. Water Resources Research 46, W10507. doi:10.1029/2009WR008315

Wainwright J, Parsons AJ (2002) The effect of temporal variations in rainfall on scale dependency in runoff coefficients. Water Resources Research 38, 1271. doi:10.1029/2000WR000188

Wainwright J, Parsons AJ, Abrahams AD (2000) Plot-scale studies of vegetation, overland flow and erosion interactions: case studies from Arizona and New Mexico. Hydrological Processes 14, 2921-2943. doi:10.1002/1099-1085(200011/12)14:16/17<2921::AID-HYP127>3. $0 . \mathrm{CO} ; 2-7$

Wei H, Nearing MA, Stone JJ, Guertin DP, Spaeth KE, Pierson FB, Nichols MH, Moffett CA (2009) A new splash and sheet erosion equation for rangelands. Soil Science Society of America Journal 73, 1386-1392. doi:10.2136/SSSAJ2008.0061 
Western Regional Climate Center (WRCC) (2009) Western US climate historical summaries (individual stations). Available at http://www. wrcc.dri.edu/Climsum.html. [Verified 23 September 2009]

Wilcox BP, Pitlick J, Allen CD, Davenport DW (1996) Runoff and erosion from a rapidly eroding pinyon-juniper hillslope. In 'Advances in hillslope processes.' (Eds MG Anderson, SM Brooks.) Vol. 1, pp. 61-77. (Wiley: New York)

Wilcox BP, Breshears DD, Allen CD (2003) Ecohydrology of a resourceconserving semiarid woodland: effects of scale and disturbance. Ecological Monographs 73, 223-239. doi:10.1890/0012-9615(2003) 073[0223:EOARSW]2.0.CO;2
Williams CJ, Pierson FB, Robichaud PR, Boll J (2014a) Hydrologic and erosion responses to wildfire along the rangeland-xeric forest continuum in the western US: a review and model of hydrologic vulnerability. International Journal of Wildland Fire 23, 155-172. doi:10.1071/ WF12161

Williams CJ, Pierson FB, Al-Hamdan OZ, Kormos PR, Hardegree SP, Clark PE (2014b) Can wildfire serve as an ecohydrologic thresholdreversal mechanism on juniper-encroached shrublands? Ecohydrology 7, 453-477. doi:10.1002/ECO.1364 